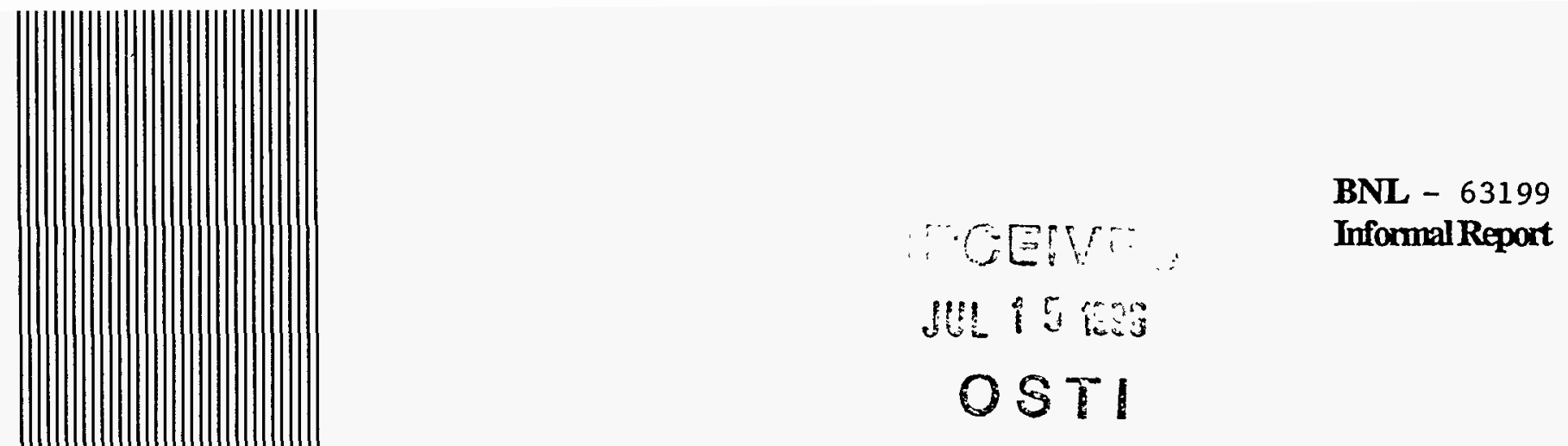

LATEX-MODIFIED GROUTS FOR IN-SITU STABILIZATION OF BURIED TRANSURANIC/MUXED WASTE

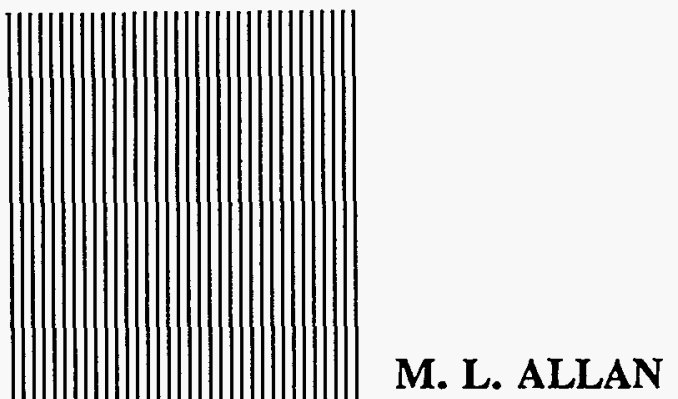

JUNE 1996

Prepared for:

Idaho National Enginering Laboratory

Idaho Falls, Idaho

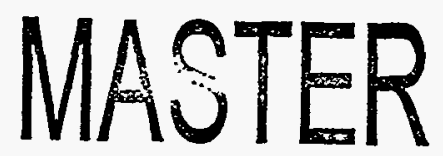

\author{
Energy Efficiency \\ and Conservation Division
}

PISTRIEUTION OF THIS DOCUNENT IS UNRATIED DEPARTMENT OF APPLIED SCIENCE

BROOKHAVEN NATIONAL LABORATORY UPTON, LONG ISLAND, NEW YORK 11973

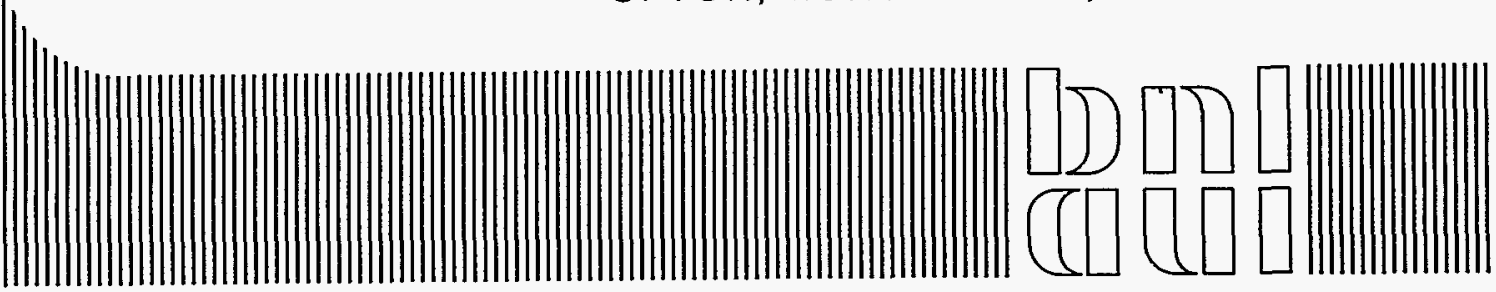




\section{DISCLAIMER}

This report was prepared as an account of work sponsored by an agency of the United States Government. Neither the United States Government nor any agency thereof, nor any of their employees makes any warranty, express or implied, or assumes any legal liability or responsibility for the accuracy, completeness, or usefulness of any information, apparatus, product or process disclosed, or represents that its use would not infringe privately owned rights. Reference herein to any specific commercial product, process, or service by trade name, trademark, manufacturer, or otherwise, does not necessarily constitute or imply its endorsement, recommendation, or favoring by the United States Government or any agency thereof. The views and opinions of authors expressed herein do not necessarily state or reflect those of the United States Government or any agency, contractor, or subcontractor thereof. 


\title{
LATEX-MODIFIED GROUTS FOR IN-SITU STABILIZATION OF BURIED TRANSURANIC/MIXED WASTE
}

\section{MARITA L. ALLAN}

JUNE 1996

\author{
Prepared for: \\ Idaho National Engineering Laboratory \\ Idaho Falls, Idaho
}

\author{
Energy Efficiency and Conservation Division \\ Department of Applied Science \\ Brookhaven National Laboratory \\ Upton, New York 11973-5000
}

This work was performed under the auspices of the U.S. Department of Energy, Washington, DC, under Contract No. DE-AC02-76CH00016. 


\section{CONTENTS}

LIST OF TABLES.

LIST OF FIGURES.

iv

SUMMARY.

$\mathrm{v}$

vi

1.0 Introduction.

2.0 Latex Admixtures.

3.0 Description of Jet Grouting.

3.1 Materials for Jet Grouting.

4.0 Experimental Materials and Procedure.

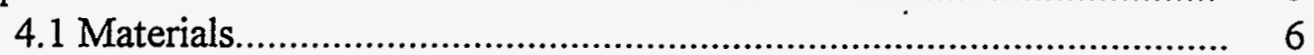

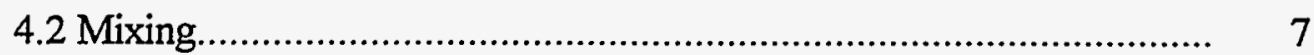

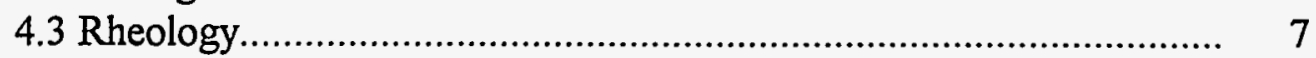

4.4 Mix Proportions of Soil Cements...................................................... 8

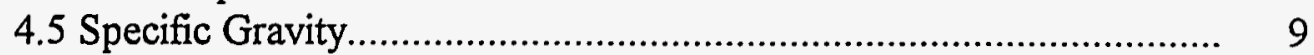

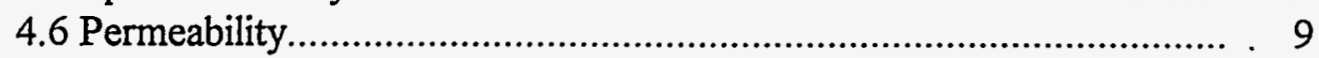

4.7 Compressive Strength....................................................................... $9^{\text {' }}$

4.8 Antifoam Evaluation................................................................... 9

5.0 Results.

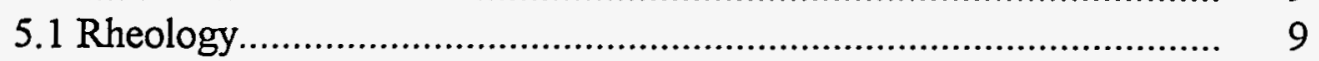

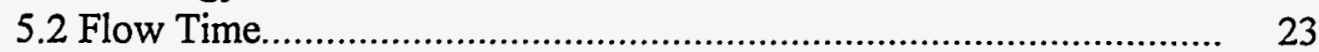

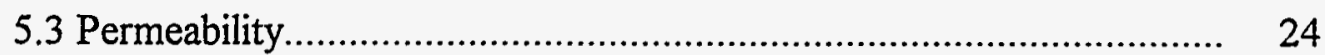

5.4 Compressive Strength.................................................................. 25

5.5 Antifoam Evaluation.................................................................. 25

6.0 Material Cost Estimates for Latex-Modified Grouts..................................... 25

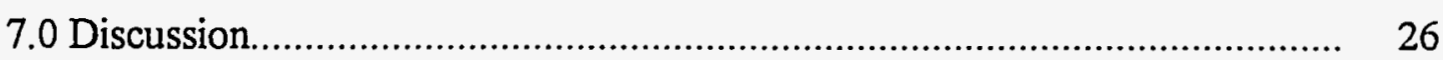

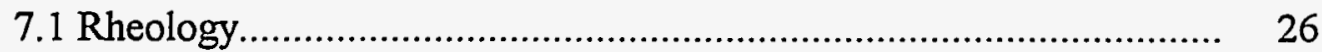

7.2 Mixing Procedure..................................................................... 27

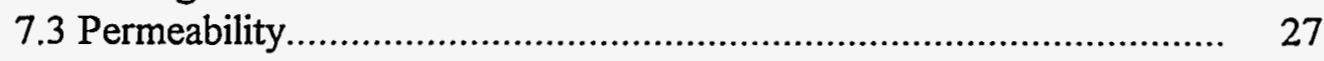

7.4 Compressive Strength................................................................. 28

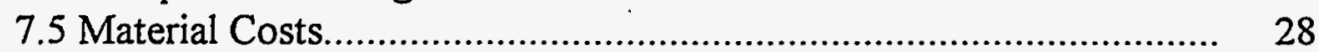

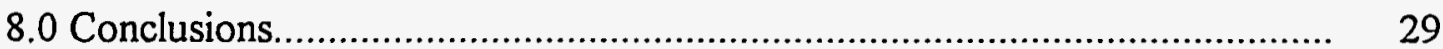

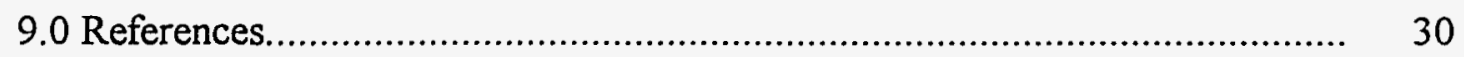





\section{LIST OF TABLES}

Table 1 Mix Proportions of Soil Cements... 8

Table 2 Rheology Data for Neat Cement Grouts.

Table 3 Rheology Data for Superplasticized Styrene ButadieneModified Grouts.

Table 4 Rheology Data for Superplasticized Acrylic-

Modified Grouts.

Table 5 Rheology Data for Superplasticized Styrene

Butadiene-Modified Grouts Containing Fly Ash 23

Table 6 Rheology Data for Superplasticized Acrylic-

Modified Grouts Containing Fly Ash. 23

Table 7 Flow Times of Grouts Mixed in Planetary Mixer. 24

Table $8 \quad$ Permeability Results for Soil Cements........................................... 24

Table 9 Compressive Strength Results for Soil Cements..................................... 25

Table $10 \quad$ Materials Cost Estimates for Grouts............................................. 26 



\section{LIST OF FIGURES}

Page

Figure 1 Effect of Water/Cement Ratio on Shear Stress-Shear Rate Curve for Neat Cement Grouts.

Figure 2 Shear Stress-Shear Rate Curve for Latex-Modified Grouts with $\mathrm{w} / \mathrm{c}=0.6, \mathrm{p} / \mathrm{c}=0.05$.

Figure 3 Shear Stress-Shear Rate Curve for Latex-Modified Grouts with $\mathrm{w} / \mathrm{c}=0.6, \mathrm{p} / \mathrm{c}=0.15$.

Figure 4 Effect of Water/Cement Ratio on Shear Stress-Shear Rate Curve for Styrene Butadiene-Modified Grouts with $\mathrm{p} / \mathrm{c}=0.05$.

Figure 5 Effect of Water/Cement Ratio on Shear Stress-Shear Rate Curve for Acrylic-Modified Grouts with $\mathrm{p} / \mathrm{c}=0.05$.

Figure 6 Effect of Water/Cement Ratio on Shear Stress-Shear Rate Curve for Styrene Butadiene-Modified Grouts with $\mathrm{p} / \mathrm{c}=0.15$. 16

Figure 7 Shear Stress-Shear Rate Curve for Latex-Modified Grouts with $40 \%$ Fly Ash, w/cm $=0.6, \mathrm{p} / \mathrm{cm}=0.05$

Figure 8 Shear Stress-Shear Rate Curve for Latex-Modified Grouts with $40 \%$ Fly Ash, $w / \mathrm{cm}=0.6, \mathrm{p} / \mathrm{cm}=0.15$

Figure 9 Shear Stress-Shear Rate Curve for Latex-Modified Grouts with $40 \%$ Fly Ash, $w / \mathrm{cm}=0.45, \mathrm{p} / \mathrm{c}=0.05$

Figure 10 Effect of Superplasticizer on Shear Stress-Shear Rate Curve for Acrylic-Modified Grout with w/c $=0.6, p / c=0.15$ 20

Figure 11 Effect of Mixer on Shear Stress-Shear Rate Curve for AcrylicModified Grout with $w / \mathrm{c}=0.45$ and $0.6, \mathrm{p} / \mathrm{c}=0.05$ 


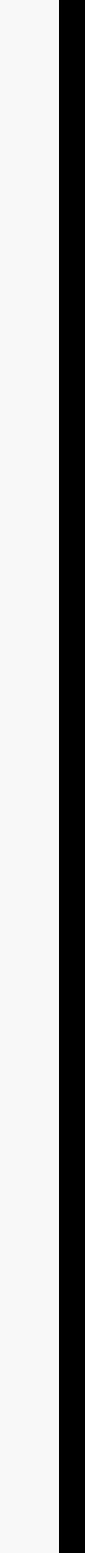




\section{SUMMARY}

Preliminary research was conducted to investigate latex-modified grouts for in-situ stabilization of buried transuranic/mixed waste for Idaho National Engineering Laboratory (INEL). The grouts are candidates for jet grouting shallow land burial pits at the INEL site, in addition to other sites requiring remediation. Through appropriate mix design, admixtures, and correct execution of grouting, the crack resistance and durability of cementitious grout can be optimized.

The rationale for using latex as a grout admixture was to improve binding of contaminants and thus reduce risk of exposure. Styrene butadiene and acrylic latexes were used. Superplasticizers were added to grouts to enable reduction of water/cementitious material ratio $(w / \mathrm{cm})$ while maintaining low viscosity. Fly ash was added to reduce of heat of hydration and improve durability.

The effects of latex content, w/cm, fly ash, and mixing procedure on grout rheology was determined. Suitable rheological properties were obtained with superplasticized, latex-modified grouts with $w / \mathrm{cm}=0.45-0.6$ and polymer solids $/$ cementitious material $=0.05-0.15$.

Selected latex-modified grouts were mixed with uncontaminated INEL soil and limited permeability (hydraulic conductivity) and compressive strength test were performed. Permeability of soil cements with a total $w / \mathrm{cm}=0.76$ was of the order of $10^{-10} \mathrm{~cm} / \mathrm{s}$, while mixes with $\mathrm{w} / \mathrm{cm}=0.96$ had permeabilities of the order of $10^{-9} \mathrm{~cm} / \mathrm{s}$. Soil cements prepared with neat cement grout had permeabilities ranging from $10^{-8}-10^{-7} \mathrm{~cm} / \mathrm{s}$, depending on curing conditions. Compressive strength of latex-modified soil cements was strongly influenced by curing and typically ranged form 9 to 17 $\mathrm{MPa}$. The results for field mixing and curing conditions can be expected to differ from those produced on a laboratory scale.

The estimated material cost of superplasticized, latex-modified grouts ranges from \$1-3/U.S. gallon, depending on mix proportions and latex type. The latex-modified grouts are safe and easy to work with and grouting equipment can be readily cleaned with water. It is recommended that any jet grouting field trials and subsequent evaluation of latex-modified grout be conducted in conjunction with an unmodified grout with the same w/cm in order to quantify the actual benefits of latex. This will provide a valid technical reason for justifying the additional cost of latex. Other issues requiring further investigation include the effect of subsurface curing conditions on latex film formation and resultant properties of the treated soil/waste, appropriate field mixing procedure and antifoam dosage to control air entrainment, and compatibility with jet grouting.

Ultimately, the success of the latex-modified grouts or any other material will depend on many factors in the design and execution stages. Laboratory tests are only one component of a well engineered grouting project. It is not possible to reach a definitive conclusion on the performance of the developed latex-modified grouts for buried waste stabilization without field demonstration and evaluation. However, the results obtained were positive and further investigation is warranted. 


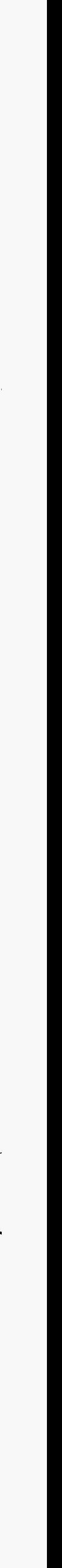




\subsection{INTRODUCTION}

Under TTP CH3-6-LF-23, Task A2, the Department of Applied Science at Brookhaven National Laboratory was requested to investigate latex-modified grouts for in-situ stabilization of buried TRU/mixed waste for INEL. The waste exists in shallow trenches that were backfilled with soil. The objective was to formulate latex-modified grouts for use with the jet grouting technique to enable in-situ stabilization of buried waste. The stabilized waste was either to be left in place or retrieved for further processing. Grouting prior to retrieval reduces the potential release of contaminants.

Rheological properties of latex-modified grouts were investigated and compared with those of conventional neat cement grouts traditionally used for jet grouting. Limited permeability and compressive strength tests of grout-treated INEL soil were conducted. The variables and properties that could be tested were also limited. Hence, a preliminary assessment is presented.

Grouting materials and methods for stabilization of shallow land burial trenches at INEL have been under study for several years. For example, research was conducted at Oak Ridge National Laboratory in FY 1986 and the results of grout testing and cost analysis for in-situ stabilization are available (Tallent et al., 1987; Spence, 1987).

\subsection{LATEX ADMIXTURES}

The use of latex to improve grout quality was of interest for the task. Latex for modification of cementitious materials is typically produced by emulsion polymerization. The emulsion consists of submicron polymer particles dispersed in water. Modification with redispersible polymer powders is also possible. Latex is widely used to improve certain properties of concrete, mortar, grout, and shotcrete. Common applications of latex-modified materials are bridge deck overlays, parking structures and concrete repair. Another use of latex is in oil well cement slurries (Vorkinn and Sanders, 1993; Paftis, 1995). Addition of latex to cementitious materials improves tensile and flexural strengths, increases ductility, reduces elastic modulus, improves bond strength, and enhances resistance to freeze-thaw degradation. Patch repair mortars usually contain latex to ensure sound adhesion to old concrete. Hydraulic conductivity (coefficient of permeability) of concrete is reduced by latex and resistance to shrinkage cracking is improved. Latex-modified materials exhibit greater resistance to chemical attack than unmodified counterparts. Slight retardation may occur. Further information on the properties of latex-modified materials is available elsewhere (Ohama, 1984; Lavelle, 1988; ACI 548, 1990; Nishi et al., 1990; Walters, 1990; Chandra and Ohama, 1994).

The type of latex has a strong influence on the properties of the final product. Two of the more common types used to modify cementitious materials were selected for investigation. These were carboxylated styrene butadiene and acrylic. It is important to understand the principles of latex modification in order to take advantage of this additive. This is discussed by Ohama (1984) and Lavelle (1988). Cement hydration begins and latex particles become confined to voids and capillaries. As water is removed by cement hydration reactions and evaporation, the latex particles coalesce into 
a continuous film. It is this film that imparts the properties of interest such as reduced permeability, crack bridging and enhanced toughness. Thus, film formation is critical. Factors affecting film formation include temperature, time, curing conditions, and the physical and chemical properties of the latex.

A major difference between latex-modified and unmodified cementitious materials is the curing conditions required for optimum properties. Unlike conventional mortar and concrete where moist curing is necessary, optimum properties of latex-modified materials are usually achieved by a one to three day moist cure followed by air curing at $50 \%$ relative humidity. Curing by immersion in water will prevent film formation. Hence, latex-modified materials are not suitable for underwater applications. It is also important that the material not be subjected to rapid drying at any time.

The question arises as to how film formation will be achieved in the grout-treated soil for subsurface curing conditions. The soil surrounding that which is jet grouted will provide protection from rapid water loss and initial curing conditions can be classified as moist. Latex coalescence and film formation will occur as water reacts during the cement hydration process, but dehydration will be slower than that for atmospheric conditions. Therefore, the age of the grouted soil will influence the properties. This point must be considered when testing after grouting.

Another issue concerns the appropriate laboratory curing of soil mixed with latex-modified grout. Curing conditions of laboratory prepared specimens will influence the soil cement behaviour. Since soil cements are much weaker than other traditional latex-modified materials (e.g., concrete, mortar), sufficient time should be allowed for the soil cement to develop adequate strength before durability testing. This is particularly true for some of the proposed mixes containing fly ash which have a slower rate of strength development. The age at testing needs to be representative of the ultimate properties achieved when the material cures in-situ.

Latex can be used to improve the properties of grouts and an example of this for posttensioning ducts is described by Lankard et al. (1993). Treatment of soil with natural rubber latex alone has been investigated for stabilization and erosion control (Bernas et al., 1995a; b). A literature survey did not reveal any published previous case histories of latex-modified grouts for jet grouting. McFarlane and Holtz (1992) studied latex admixtures for improving the flexibility of soilcement-bentonite cutoff walls produced by soil mixing. Styrene butadiene and acrylic latexes were tested. The latexes were added to cement-bentonite grouts which were then either mixed with a sand or a silt. It was found that compressive strength and modulus of elasticity were decreased by latex. The styrene butadiene latex increased tensile and flexural strength for the sand mix, whereas the acrylic latex did not improve these properties. Permeability of the treated sand was not significantly decreased by latex, whereas a permeability decease occurred for the treated silt. However, the treated soils were cured at $100 \%$ relative humidity and latex film formation may not have been complete at testing.

The amount of latex added to mortar and concrete is usually in the range of 5 to $20 \%$ polymer solids by mass of cement. Higher levels can result in bleeding of the latex and are uneconomic. 
Formulations of latex-modified materials must take into account the contribution of water in the latex in the overall water/cementitious material ratio. Latex cannot be expected to compensate for poor mix design such as excessive water/cementitious material ratio, improper mixing, or poor construction practices. The use of latex is therefore usually confined to high performance products with low water/cementitious material ratios. Hence, it is necessary to reduce water content of the grout for insitu stabilization as much as possible to utilize the benefits of latex.

Latex has a minimum film formation temperature around $5-12^{\circ} \mathrm{C}$, depending the type of latex. Therefore, the latex-modified material should not be placed at temperatures below the characteristic value. The modified material sets in a predictable and reliable manner, unlike highly exothermic resins. Clean up of equipment used to mix latex-modified materials requires water and latex does not pose any health, safety, or environmental threats. Latex is very adherent to most surfaces and equipment must be cleaned immediately and thoroughly after use.

\subsection{DESCRIPTION OF JET GROUTING}

Applications of jet grouting include formation of subsurface impermeable barriers, structural underpinning, in-situ stabilization of hazardous waste, slope stabilization, and tunnel construction. Examples of case histories are supplied by Bruce (1995), Welsh and Burke (1995), Bell (1994), Tarricone (1994), Burke and Brill (1993), Gallavresi (1992), and Raabe and Toth (1989). Jet grouting can be applied to a broad spectrum of soil types including fine soils where uniform and consistent penetration of particulate grouts by permeation is difficult to achieve. Such appears to be the case at the INEL site which has a fine silty-clay type soil. Thus, jet grouting for stabilization of buried waste and contaminated plumes is highly pertinent to the INEL and other DOE sites.

The jet grouting procedure basically involves drilling to the required depth, followed by high pressure injection of grout through nozzles during withdrawal of the rotating monitor. The physical and mechanical properties of the final product depend on the soil type, grout mix proportions (particularly water/cement ratio), moisture conditions of the soil when grouted, cement content, and type of jet grouting system.

There are three major types of jet grouting systems known as one, two, and three-fluid [or single (S), double (D), and triple (T)]. The differences between these different systems have been described by several authors including Bruce (1995); Welsh and Burke (1995); Kauschinger et al. (1992); and Gallavresi (1992). The one-fluid system is the simplest and involves direct mixing of an erosive jet of grout with the soil to form soil cement (sometimes termed "soilcrete" or "grout-treated soil"). In the two-fluid system the grout jet is shrouded by compressed air. The compressed air assists in break up of the soil, with the result that the column diameter is greater than that achieved with the one-fluid system for the same soil conditions. Increased column diameter improves productivity. Lower strength of the final product is associated with the two-fluid system due to higher air content. This should not be a problem since the stabilized waste is not required to have a high strength. While economics, column diameter and strength are important, these factors must be balanced against specific requirements for in-situ stabilization. Leach resistance, hydraulic 
conductivity, compatibility, and durability must be considered when selecting the jet grouting system.

The triple-system employs a water jet shrouded by compressed air which is located above the grout jet. The water jet erodes the soil. This system has a higher degree of soil replacement than the one- and two-fluid systems. Column diameter is also highest for the three-fluid system. The one- and two-fluid systems are of more relevance to the in-situ stabilization task. However, the three-fluid system should be considered for containment barriers due to its versatility and the properties obtained. Another variation of jet grouting for barrier construction involves complete removal of soil by airwater jetting and the resultant cavity is tremied with grout or concrete. Sanded and fibre reinforced grouts for this technique were investigated for the Mixed Waste Landfill Integrated Demonstration (Allan and Kukacka, 1994a; b; 1995).

Further details of the jet grouting technique are given by Bruce (1995), Welsh and Burke (1995), Bell (1994), Gallavresi (1992), Kauschinger et al., (1992), Parry-Davies et al., (1992), and Gazaway and Jasperse (1992).

In addition to the jet grouting rig, other necessary equipment include an automatic batch plant, a grout mixer of suitable efficiency and capacity, an agitator for mixed grout storage, a high pressure pump that can continuously supply grout at a high flow rate, flow meters, and means of monitoring grout quality and grouting parameters. This is regarded as standard equipment. A high speed, high shear "colloidal" mixer is preferred for most cementitious grouts due to improved mixing efficiency and resultant high quality product. Different types of mixing equipment are described by Houlsby (1990) and Gourlay and Carson (1982) and various papers describing mixers used in jet grouting are included in Bell (1994). Examples of manufacturers that supply suitable grout plants include ChemGrout, Häny, Colcrete. High shear mixers have the advantages of ability to mix grouts at low water/cement ratio, reduced necessity for admixtures, improved rheology and stability, and rapid mixing. The quality of cementitious grout is of great importance and the use of drill mixers or transit/ready mix trucks for mixing is unacceptable for quality jet grouting. Transit trucks are particularly unsuited to latex-modified materials, including concrete (ACI 548, 1990).

An issue raised throughout this investigation was the most appropriate method for mixing latex-modified grout. Special care is necessary to avoid entrainment of air since latexes tend to foam. Thus, the mixing procedure differs from that for conventional cementitious grout. Mixing of latexmodified grouts is discussed further in Section 4.2.

Prior to any jet grouting work it is necessary to perform thorough site investigation of pertinent soil properties and full-scale trials to delineate appropriate grouting parameters for the site conditions. This is a standard component of quality jet grouting. Each site is unique and it is necessary to establish the grouting parameters in trials before proceeding to the full operation. The variables that can be controlled are grout pressure, withdrawal rate, number and diameter of nozzles, and rod rotation rate, in addition to grout mix proportions. Air pressure is another factor if an air shroud is used. The test columns produced for a range of parameters are assessed in terms of diameter, strength, or some other property of interest, and the best combination selected. Changes 
in selected parameters throughout the project may be necessary to accommodate changes in soil conditions or to meet acceptance standards.

\subsection{MATERIALS FOR JET GROUTING}

The choice of grout mix proportions used in jet grouting is based on target properties (e.g., strength, permeability, durability), soil conditions, and economics. Geotechnical applications typically use neat cement grouts with water/cement ratio of 0.5-1.2. In some cases bentonite and/or pozzolans are added to the grout. For the case at hand, binding of contaminants and durability are of prime concern. This dictates use of a low water/cementitious material ratio $(\mathrm{w} / \mathrm{cm})$, with possible addition of beneficial additives. Superplasticizers and water reducers can be used achieve low viscosity while retaining a low value of $w / \mathrm{cm}$.

Pozzolanic materials are used as partial cement replacements to improve grout properties. Such supplementary cementing materials can reduce heat of hydration and improve resistance to aggressive species (e.g., sulphates). Mass concrete (e.g., dams) takes advantage of supplementary cementing materials to control temperature rise and thereby avoid cracking associated with thermal gradients. These materials can be used to advantage in jet grouting. An example of the use of fly ash in jet grouting is given by Bell and Burke (1994). Ground granulated blast furnace slag has also been used in grouts to reduce heat of hydration (Coutts et al., 1994) and was used at a field trail for the Mixed Waste Landfill Integrated Demonstration (Allan and Kukacka, 1994a). Any thermal cracking is preventable through use of fly ash or blast furnace slag. Low thermal conductivity of soil surrounding jet grouted columns, combined with the relatively low thermal conductivity of cementitious materials, retards heat dissipation. Internal temperatures of $43^{\circ} \mathrm{C}$ four weeks after jet grouting have been reported (Newman et al., 1994). Slow cooling should be advantageous, since thermal cracking is associated with rapid, unprotected cooling and high temperature differentials. Therefore, grouted waste that is to be retrieved should not be exposed until the differential between internal and external temperature is small.

Heat generation is not limited to cementitious grouts since polymer resins and some chemical grouts also exhibit rapid and high exotherms. Resins and chemical grouts producing high exothermic heat are prone to shrinkage and cracking on curing as a result of thermal expansion. Another consequence of high exotherms is thermal expansion of buried metal objects. The buried waste to be grouted may include metals which are subject to thermal expansion. This applies to all grouting materials under consideration, not just cementitious. Coutts et al., (1994) report on the use of blast furnace slag in cementitious grout to prevent differential movement of steel piles during the exothermic period. 
In summary, jet grouting with cementitious grouts is an established technique and the experience gathered from geotechnical applications is highly relevant to remediation of DOE sites. By utilizing the existing expertise of geotechnical grouting contractors DOE can avoid "reinventing the wheel" and prevent "false negative" assessment of jet grouting and grouting materials.

\subsection{EXPERIMENTAL MATERIALS AND PROCEDURE}

\subsection{Materials}

The grouts were based on ASTM Type I Portland cement. The liquid superplasticizer used contained $42 \%$ naphthalene sulphonate formaldehyde condensate. The dosage of superplasticizer (SP) was $20 \mathrm{ml} / \mathrm{kg}$ ( $0.32 \mathrm{fl} . \mathrm{oz} . / \mathrm{b}$ ) of total cementitious materials. This corresponds to a level of $1.0 \%$ solids by mass of total cementitious materials. Class F fly ash, conforming to ASTM C 618-94a, was supplied by Pozzolanic International and used as a supplementary cementing material in some of the grout formulations. The proportion of fly ash added was $40 \%$ by mass of (cement + fly ash). Higher levels are possible. An alternative to Class $\mathrm{F}$ fly ash is Class $\mathrm{C}$, which has a lower calcium content. Addition of ground granulated blast furnace slag may also be beneficial. The funding level did not permit the study of Class $\mathrm{C}$ fly ash, nor slag, nor was variation in the fly ash level investigated. Any future studies should optimize the fly ash level and consider use of slag.

Two latexes, styrene butadiene copolymer and acrylic, were used. The styrene butadiene was Tylac 68009-00 supplied by Reichold Chemicals. Since completing the work, Tylac 68009-00 has been replaced with Tylac 68014-00. The properties measured are not expected to differ greatly with these two versions of latex. The acrylic latex was Rhoplex MC76 supplied by Rohm and Haas. It is noted that several other companies also supply latexes suitable for modification of cementitious products and no endorsement or favouritism is intended. The Tylac 68009-00 has a polymer solids content of $42 \%$, whereas the Rhoplex MC76 acrylic latex has a solids content of $46-48 \%$. The latex contents of the grouts studied will be described in terms of polymer solids/cementitious material ratio $(\mathrm{p} / \mathrm{cm})$.

Latex has a tendency to foam and this must be controlled through appropriate mixing procedure and use of an effective antifoam. The Tylac latex already contained a silicone antifoam, whereas the Rhoplex latex did not. Four different antifoams were tested. These were Dow Corning 1520, Dow Corning 2210, Dow Corning Antifoam B, and Henkel NXZ.

Bentonite (sodium montmorillonite) was omitted from the latex-modified grouts. Bentonite is commonly used to improve grout stability and reduce bleed but was found unnecessary in the latexmodified grouts with low water/cementitious material ratio.

Three different batches of INEL soil were used. The first consisted of soil that had been sieved to pass through a No. 50 sieve $(297 \mu \mathrm{m})$. This soil was used to examine bonding to very fine particulates. The second batch was raw soil. The soil had a distinct chemical odour similar to that of $3 \mathrm{M} 5750$ (methacrylate) and was possibly contaminated with this material from previous grouting trials at INEL. The moisture content of the as received soil was $7 \%$. The third batch was raw soil 
with a moisture content of $11 \%$. The raw soil samples contained lumps of clay that were easily broken by hand. The moisture content of the soil used to mix with grout was adjusted to $12 \%$ to simulate the typical level found in subsurface conditions at the site. This effectively raised the water/cementitious material ratio of the final soil cement.

\subsection{Mixing}

Different laboratory mixing procedures were examined. Grouts were prepared in a 11 ( 35 fl. oz.) capacity blender, a Hobart planetary mixer, and a combination of blender and planetary mixer. The order of addition was varied depending on mixing equipment. Initially, the order of addition was water, antifoam, latex, any fly ash, cement and superplasticizer. It was found that mixing the latexmodified grout in the blender resulted in excessive air entrainment despite the use of antifoam. Part of the problem was probably caused by addition of dry, air laden solids to the latex. Therefore, the procedure was changed and latex was added last, where possible. Grouts with low w/cm $(0.45-0.55)$ and high $\mathrm{p} / \mathrm{cm}(0.15)$ could not be mixed in this manner in the blender due to excessive dryness so latex was added to the mixing water.

Another procedure investigated for grouts with $\mathrm{p} / \mathrm{cm}=0.05$ was to $\mathrm{mix}$ all ingredients except latex in the blender, followed by transfer to the low shear planetary mixer where latex was added. This is a simulation of mixing the unmodified grout in a high shear mixer, followed by transfer to an agitator (holding tank) and adding latex. The practicality of doing so requires consideration. For this procedure the order of addition for the blender was water, antifoam, any fly ash, cement and superplasticizer, followed by latex. Low shear mixing of latex reduced air entrainment. Selected grouts were totally mixed in a planetary mixer and the order of addition was water, antifoam, latex, any fly ash, cement and superplasticizer. No problems of foaming were encountered with the planetary mixer.

Soil cements were mixed in a planetary mixer. The grout was prepared as above and soil was gradually added. It is noted that this type of mixing is an inadequate simulation of the mixing achieved during jet grouting. Furthermore, it is difficult to represent the ranges of grout to soil ratios that are produced by jet grouting due to the different mixing action. This was particularly the case for the INEL soil which has a high clay content. It was not possible to mix high proportions of soil with a low water/cement ratio grout due to mixer limitations and soil characteristics. This does not imply that the grout is unsuitable since greater mixing efficiency will be achieved with high pressure jetting. The $\mathrm{w} / \mathrm{cm}$ for the latex-modified grouts to prepare soil cements was 0.6 . A lower value of $0.45-0.5$ is recommended for field application. However, the mixing equipment available dictated using $\mathrm{w} / \mathrm{cm}=0.6$.

\subsection{Rheology}

Apparent viscosity was measured with a Fann $35 \mathrm{~A}$ six speed coaxial cylinder viscometer. The grout was rotated for $60 \mathrm{~s}$ at a shear rate of $1021 \mathrm{~s}^{-1}$ (rotor speed $=600 \mathrm{rpm}$ ). The shear stress at 60 $s$ was recorded and the shear rate was decreased to $511 \mathrm{~s}^{-1}(300 \mathrm{rpm})$. The new shear stress was 
recorded after a period of $20 \mathrm{~s}$ and the shear rate was decreased to $340 \mathrm{~s}^{-1}(200 \mathrm{rpm})$. This procedure was repeated at $20 \mathrm{~s}$ increments for decreasing shear rates of $170,10.2$ and $5.1 \mathrm{~s}^{-1}$. The method is described by Smith (1990). The $20 \mathrm{~s}$ interval represents an intermediate state between maximum thixotropic breakdown at an infinite interval and minimum thixotropic breakdown at an interval of approximately zero (Powers, 1968). The grout was added to the viscometer immediately after mixing in the blender or planetary mixer and the ambient temperature was $21^{\circ} \mathrm{C}$.

The flow properties of selected grouts mixed in the planetary mixer were measured using an ASTM C 939-94a flow cone and a Marsh cone. The time of efflux, or flow time, was determined for a specific volume of grout. The flow time for $1725 \mathrm{ml}(61 \mathrm{fl}$. oz.) of water through the ASTM cone is $8 \mathrm{~s}$. The flow time for $1000 \mathrm{ml}(35 \mathrm{fl}$. oz.) of water from an initial volume of $1500 \mathrm{ml}$ through a Marsh cone is approximately $28 \mathrm{~s}$. The flow time of grouts is dependent on the type of mixer, and lower times can be expected for grout mixed in a high shear mixer.

\subsection{Mix Proportions of Soil Cements}

The mix proportions of the tested soil cements are presented in Table 1. The soil/grout ratio by mass is reported. The total water/cementitious material ratio includes water from the grout and the soil. N.B., SBR = carboxylated styrene butadiene copolymer, ACR = acrylic.

Table 1. Mix Proportions of Soil Cements

\begin{tabular}{|c|c|c|c|c|c|}
\hline $\begin{array}{c}\text { Mix } \\
\text { Code }\end{array}$ & \multicolumn{1}{|c|}{ Grout Type } & $\begin{array}{c}\text { Latex } \\
\text { Type }\end{array}$ & $\begin{array}{c}\text { Soil } \\
\text { Type }\end{array}$ & Soil/Grout & Total w/cm \\
\hline 1 & $\mathrm{w} / \mathrm{c}=1$, no admixtures or fly ash & - & Raw & 1.75 & 1.42 \\
\hline 2 & $\begin{array}{l}100 \% \text { Cement, p/cm }=0.15, \mathrm{w} / \mathrm{c}= \\
0.6\end{array}$ & SBR & Raw & 1.70 & 0.96 \\
\hline 3 & $\begin{array}{l}40 \% \mathrm{FA} / 60 \% \text { Cement, p/cm }= \\
0.05, \mathrm{w} / \mathrm{cm}=0.6\end{array}$ & ACR & Raw & 1.70 & 0.96 \\
\hline 4 & $\begin{array}{l}40 \% \mathrm{FA} / 60 \% \text { Cement, p/cm }= \\
0.15, \mathrm{w} / \mathrm{cm}=0.6\end{array}$ & ACR & Sieved & 0.84 & 0.78 \\
\hline 5 & $\begin{array}{l}40 \% \mathrm{FA} / 60 \% \text { Cement, p/cm }= \\
0.05, \mathrm{w} / \mathrm{cm}=0.6\end{array}$ & SBR & Raw & 1.70 & 0.96 \\
\hline
\end{tabular}




\subsection{Specific Gravity}

The specific gravity of grouts was measured using a Baroid mud balance following ASTM D 4380-84. An air pressurized mud balance would have been more appropriate and could have been used to determine the air content of the latex-modified grouts. Future studies should use a pressurized mud balance.

\subsection{Permeability}

The water permeability (hydraulic conductivity) of the grouts under saturated conditions was measured in a flexible wall triaxial cell permeameter on cylindrical specimens $76 \mathrm{~mm}(3 \mathrm{in}$.) diameter and $60 \mathrm{~mm}$ (2.4 in.) long. The permeant was de-aired tap water. The applied pressure gradient was $207 \mathrm{kPa}(30 \mathrm{psi})$ over the length of the specimen. The confining pressure applied to seal the latex membrane to the side surface of the grout specimen and to simulate an overburden pressure was 414 $\mathrm{kPa}(60 \mathrm{psi})$. The experimental set-up followed that given in ASTM D 5084-90.

Three specimens per batch were tested at an age of 28 days and all specimens were vacuum saturated with de-aired water prior to measurement. Volumetric flow rates in and out of the specimens were monitored and measurements commenced when equilibrium was reached.

\subsection{Compressive Strength}

The compressive strength of soil cements at an age of 28 days was measured on cylinders 76 $\mathrm{mm}$ (3 in.) diameter and $150 \mathrm{~mm}$ (6 in.) long following ASTM C 39-86. The results are reported as an average of six specimens.

\subsection{Antifoam Evaluation}

The efficiency of the different antifoams was compared in terms of height of foam produced by mixing water, antifoam and latex in the blender.

\subsection{RESULTS}

\subsection{Rheology}

The effect of w/c ratio on shear stress-shear rate behaviour for neat cement grouts mixed in the blender is shown in Figure 1. The range of w/c ratios covers the grouts commonly used for jet grouting. The figure shows the changes in rheological behaviour with water content. The grout with the highest $w / c$ behaves as a Bingham plastic in that the shear stress-shear rate is linear beyond the yield stress. At lower w/c, the grouts show shear thinning behaviour at low shear rates and thus, are not true Bingham plastics. Such grouts can be termed "false body" fluids. The degree of shear thinning increases with decreasing w/c. Note that the rheological properties are strongly dependent on mixer type and variation between the properties reported here and those achieved with a field scale 


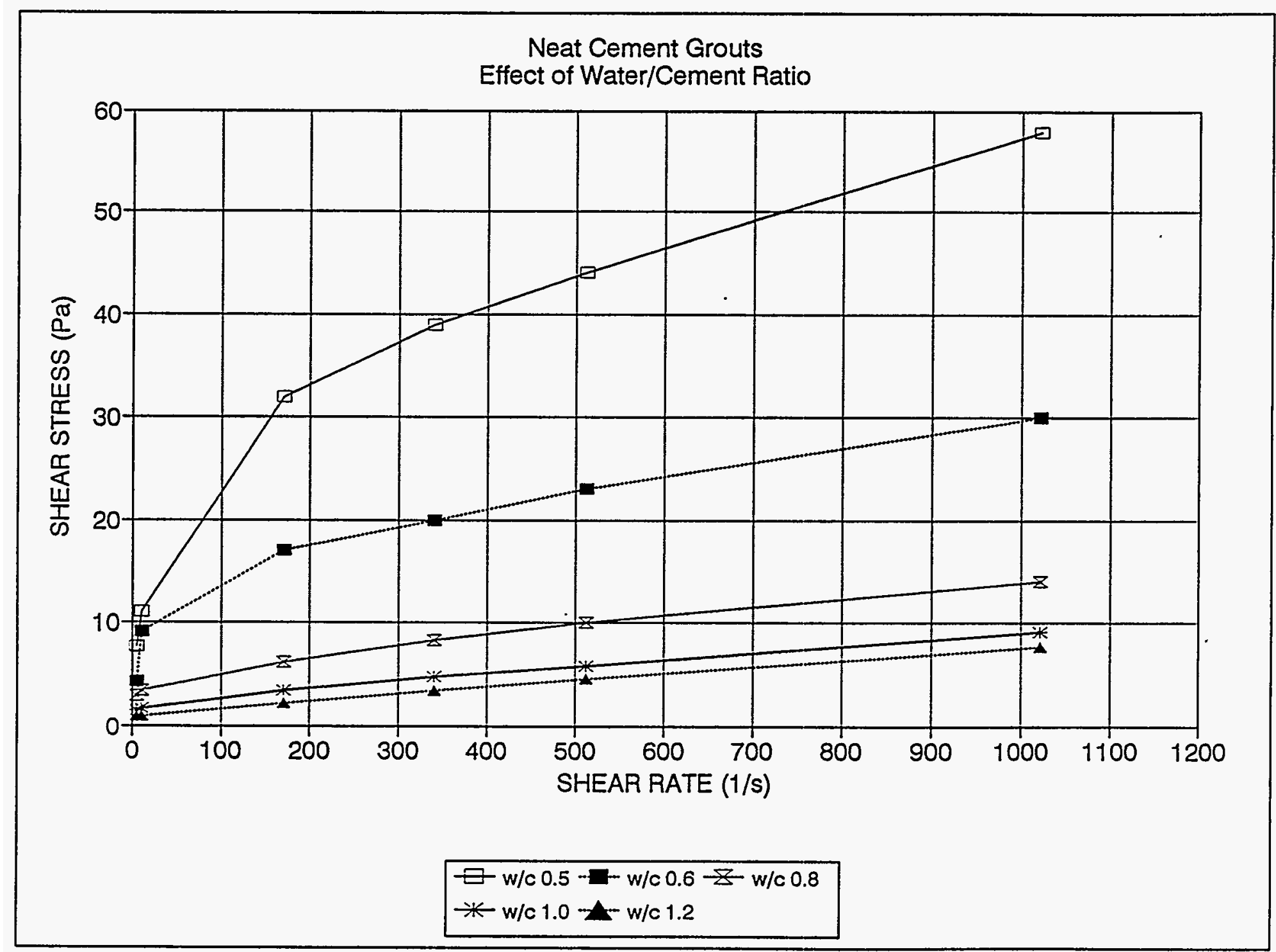

Figure 1. Effect of Water/Cement Ratio on Shear Stress-Shear Rate Curve for Neat Cement Grouts. 
colloidal mixer are inevitable. Shear and thermal history also influence rheology. However, the data allows comparison between the neat cement grouts and those modified with latex.

The shear stress-shear rate relationship for superplasticized latex-modified cementitious grouts with $\mathrm{p} / \mathrm{cm}=0.05$ and $\mathrm{w} / \mathrm{cm}=0.6$ is shown in Figure 2. These grouts, and all others shown in Figures 3-10, were mixed in the blender. The ordinate scale differs from that in Figure 1. The effect of latex type is minimal and the grouts behave approximately as Bingham plastics for the mix proportions and mixing conditions. Figure 3 shows the same type of grout with $\mathrm{p} / \mathrm{cm}$ increased to 0.15 . Shear thinning behaviour at low shear rates is evident and the acrylic latex has a lower shear stress at any given shear rate. This equates with lower viscosity at a particular shear rate.

The effect of $\mathrm{w} / \mathrm{cm}$ for superplasticized grouts with styrene butadiene latex at $\mathrm{p} / \mathrm{cm}=0.05$ is shown in Figure 4. The grout behaviour transforms from Bingham to false body as $\mathrm{w} / \mathrm{cm}$ decreases from 0.60 to 0.45 . Figure 5 shows the equivalent results for acrylic latex at $\mathrm{p} / \mathrm{cm}=0.05$. The effect of $\mathrm{w} / \mathrm{cm}$ on superplasticized grouts with $\mathrm{p} / \mathrm{cm}=0.15$ for styrene butadiene latex is shown in Figure 6.

Figures 7 and 8 depict the rheological behaviour of superplasticized, latex-modified grouts with $40 \%$ Class F fly ash with $\mathrm{p} / \mathrm{cm}=0.05$ and 0.15 , respectively. The $\mathrm{w} / \mathrm{cm}$ of these grouts was 0.6 . Comparison with Figures 2 and 3 shows that addition of $40 \%$ fly ash tends to increase shear stress for a given shear rate. The grouts with $\mathrm{p} / \mathrm{cm}=0.15$ had lower shear stresses at given shear rates than those with $\mathrm{p} / \mathrm{cm}=0.05$. The acrylic latex had lower shear rate and hence, lower viscosity, at a given shear rate compared with the styrene butadiene. This may be related to the higher amount of water added to give $\mathrm{w} / \mathrm{cm}=0.6$ as a result of the higher solids content in the acrylic latex.

The shear stress-shear rate curves for superplasticized, $40 \%$ fly ash grouts with $\mathrm{p} / \mathrm{cm}=0.05$ and a more desirable $w / \mathrm{cm}=0.45$ are shown in Figure 9. The superplasticizer was added to the mixing water to improve mixability. Although the grouts are more viscous at the lower $w / \mathrm{cm}$, comparison with Figure 1 indicates that the values of shear stress fall within those for neat cement grouts that have been successfully used in jet grouting.

The effect of superplasticizer on acrylic-modified grout with $w / \mathrm{cm}=0.6$ is depicted in Figure 10. The benefits of adding superplasticizer are clear. This benefit permits reduction of $w / \mathrm{cm}$ to $0.45-$ 0.5 while maintaining low viscosity.

Figure 11 indicates the effect of laboratory mixer type on rheological behaviour for superplasticized grouts with $\mathrm{p} / \mathrm{cm}=0.05$. Also shown is the effect of $w / \mathrm{cm}$. Low shear mixing in the planetary mixer produces a more viscous grout and this becomes more accentuated at lower $\mathrm{w} / \mathrm{cm}$.

The funding level for this project did not permit study of the properties of latex-modified grouts mixed in field scale mixers. This should be done before any jet grouting trials. The rheology 


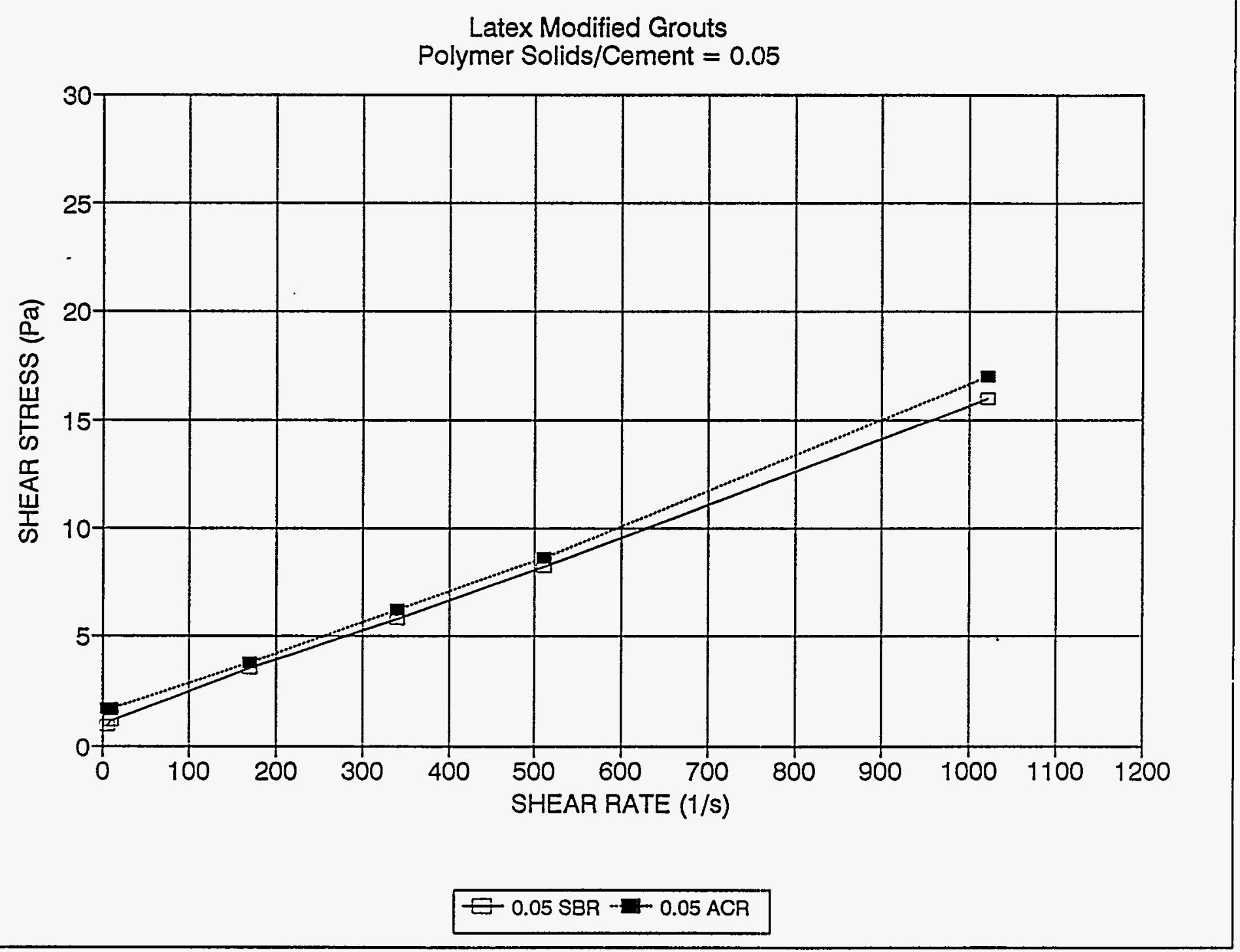

Figure 2. Shear Stress-Shear Rate Curve for Latex-Modified Grouts with $w / c=0.6, p / c=0.05$. 


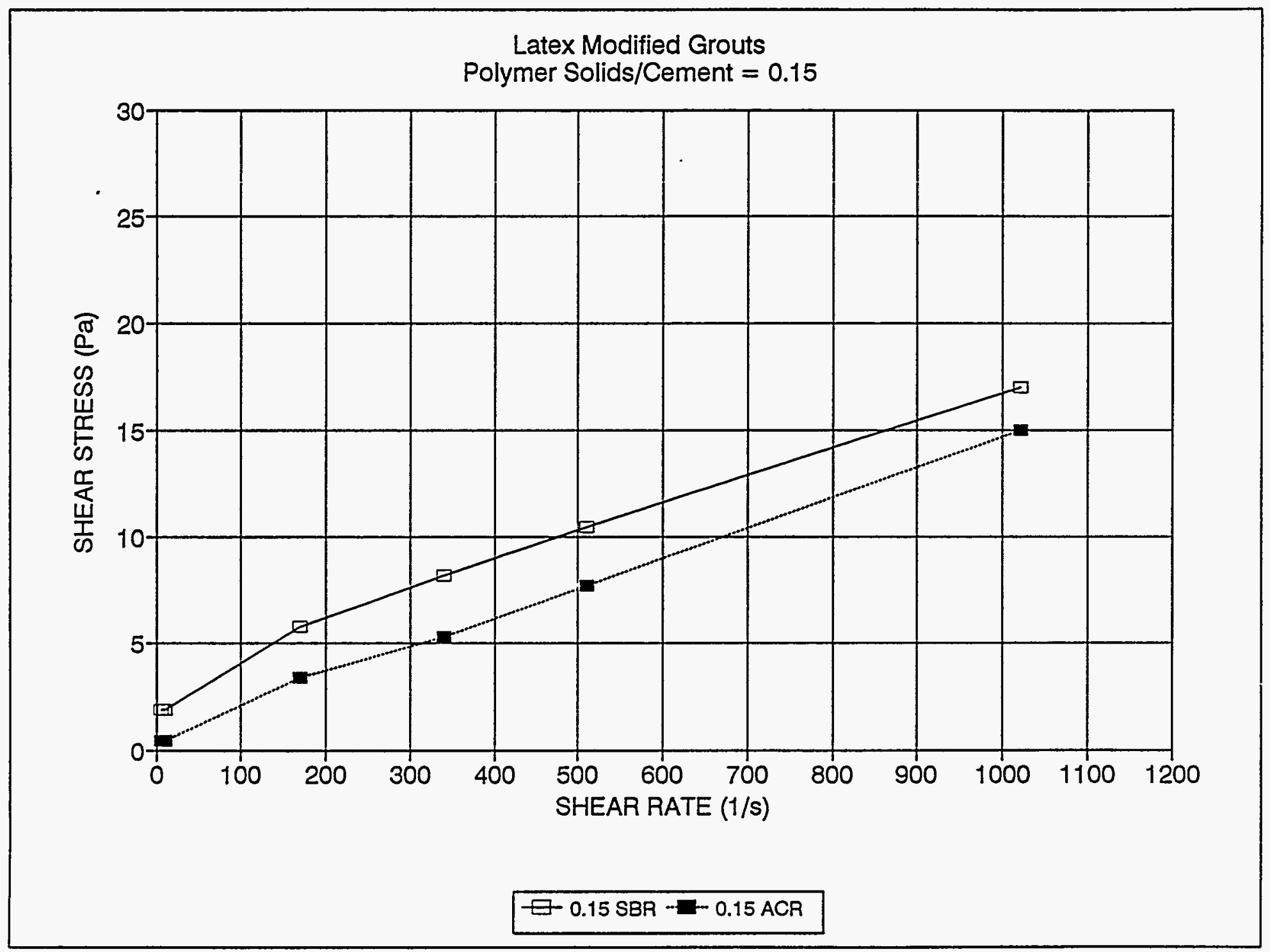

Figure 3. Shear Stress-Shear Rate Curve for Latex-Modified Grouts with $w / c=0.6, p / c=0.15$. 


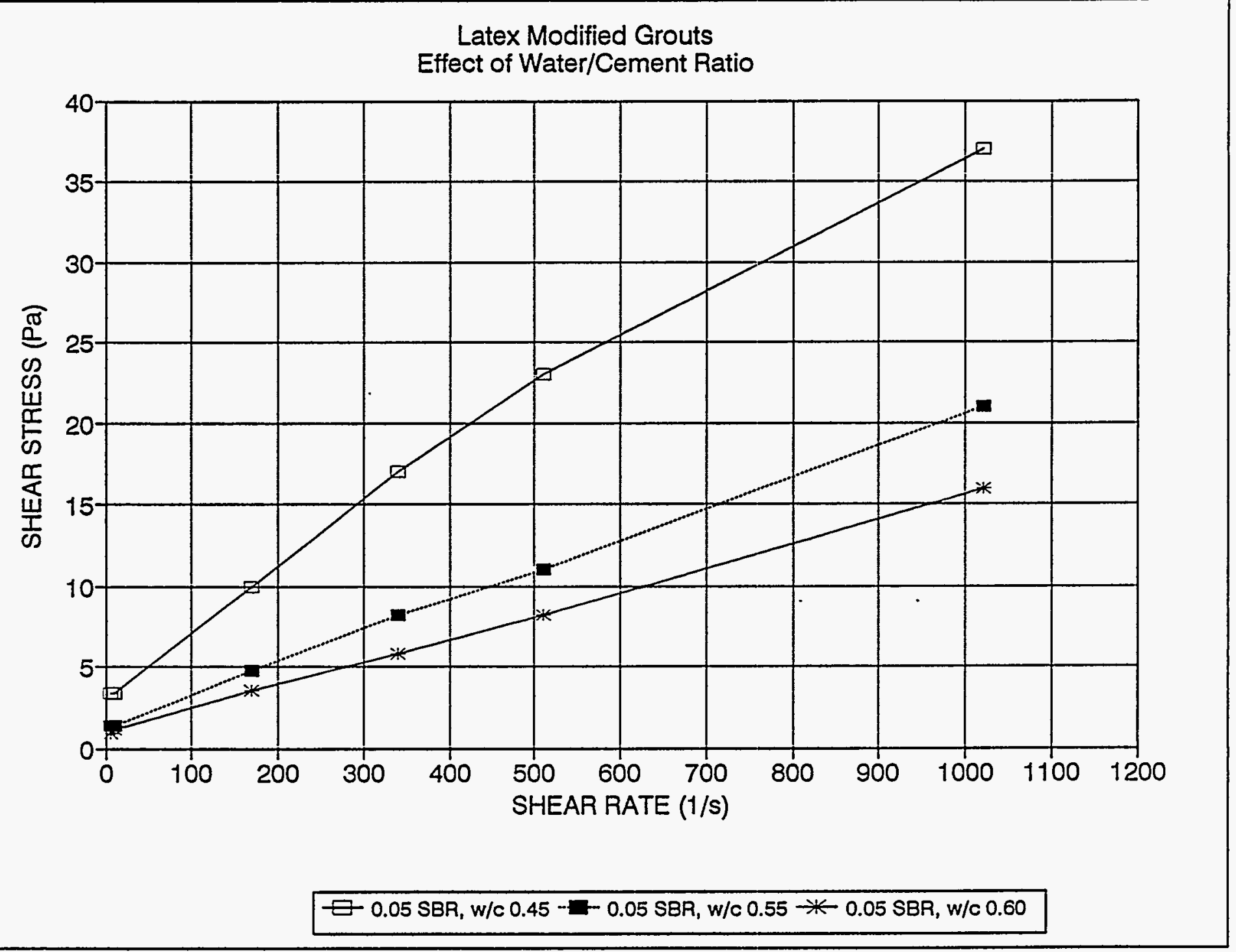

Figure 4. Effect of Water/Cement Ratio on Shear Stress-Shear Rate Curve for Styrene ButadieneModified Grouts with $\mathrm{p} / \mathrm{c}=0.05$. 


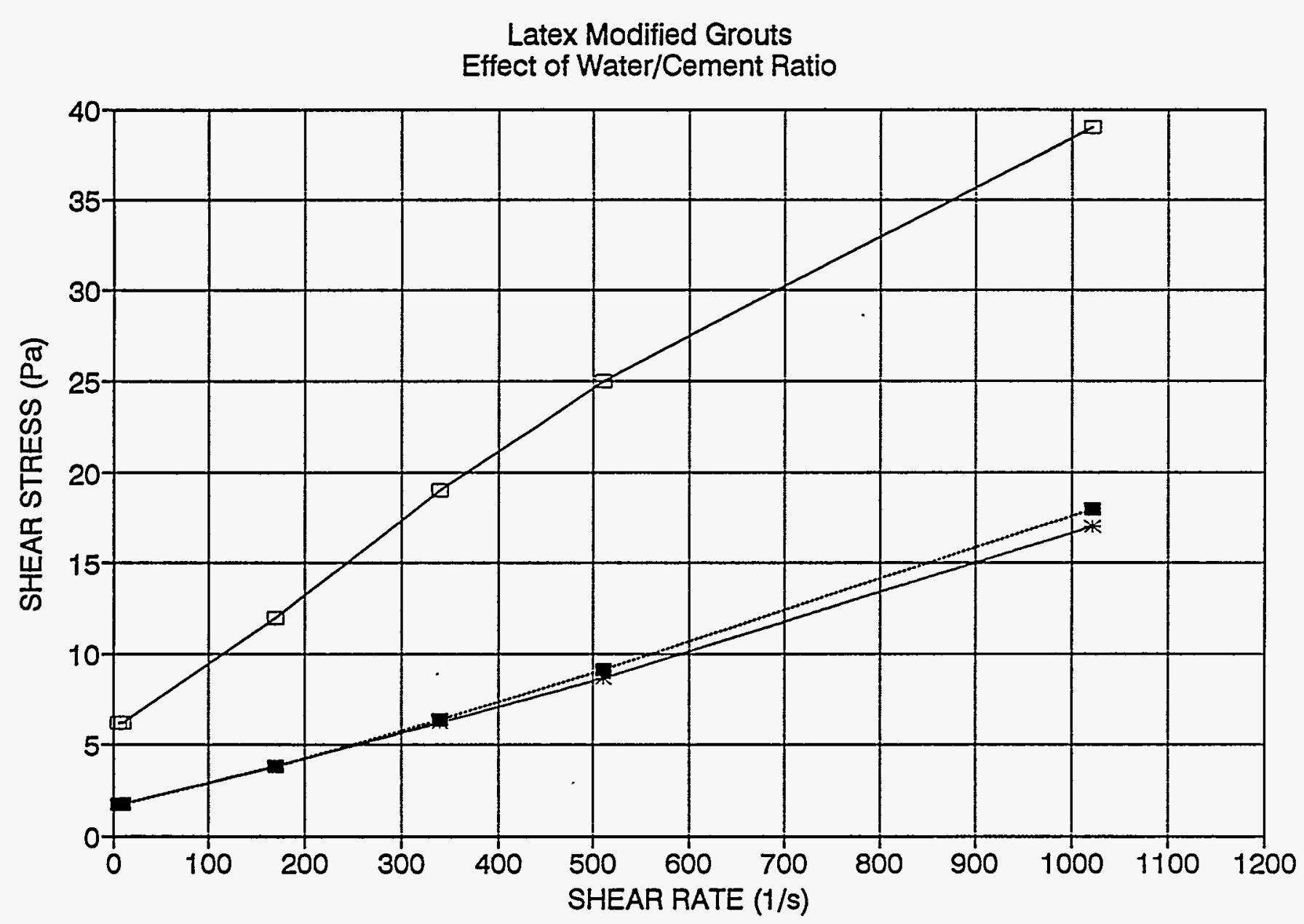

Ð0.05 ACR, w/c $0.45-0.05$ ACR, w/c 0.55 * 0.05 ACR, w/c 0.60

Figure 5. Effect of Water/Cement Ratio on Shear Stress-Shear Rate Curve for Acrylic-Modified Grouts with $\mathrm{p} / \mathrm{c}=0.05$. 


\section{Latex Modified Grouts \\ Effect of Water/Cement Ratio}

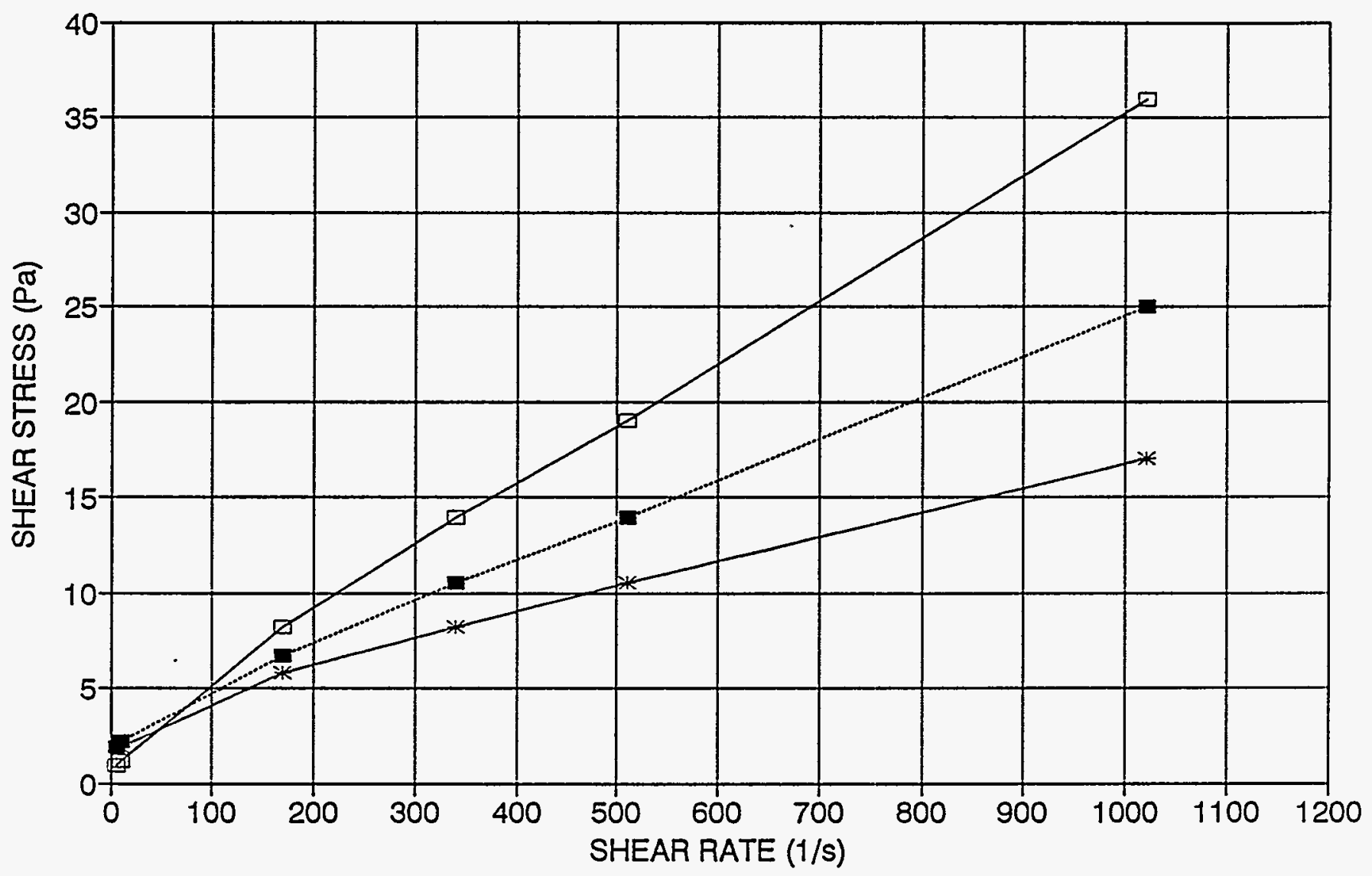

0.15 SBR, w/c $0.45-0.15$ SBR, w/c $0.50-0.15$ SBR, w/c 0.60

Figure 6. Effect of Water/Cement Ratio on Shear Stress-Shear Rate Curve for Styrene ButadieneModified Grouts with $\mathrm{p} / \mathrm{c}=0.15$. 


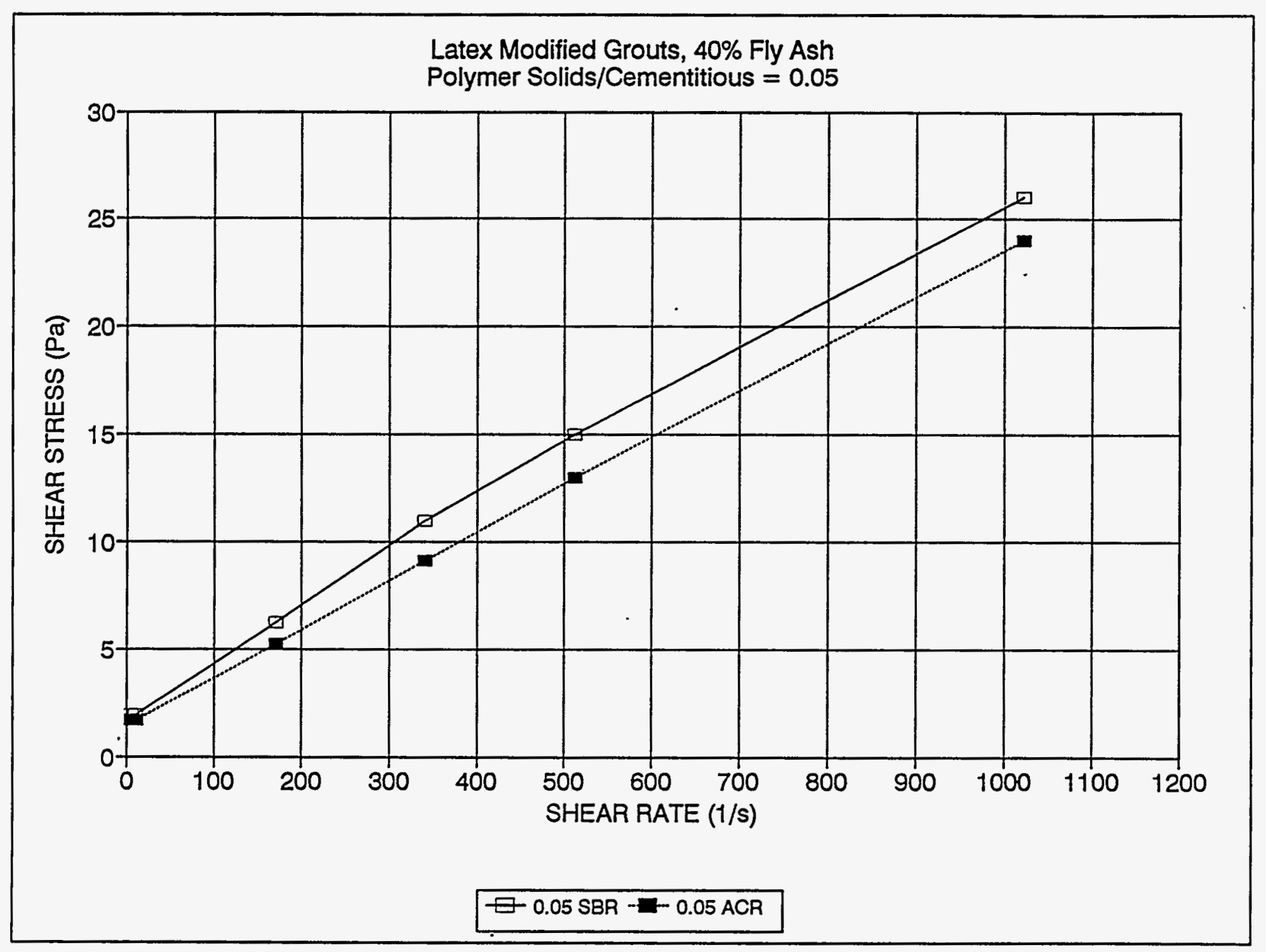

Figure 7. Shear Stress-Shear Rate Curve for Latex-Modified Grouts with $40 \%$ Fly Ash, w/ $/ \mathrm{cm}=0.6$, $\mathrm{p} / \mathrm{cm}=0.05$. 
Latex Modified Grouts, $40 \%$ Fly Ash

Polymer Solids/Cementitious $=0.15$

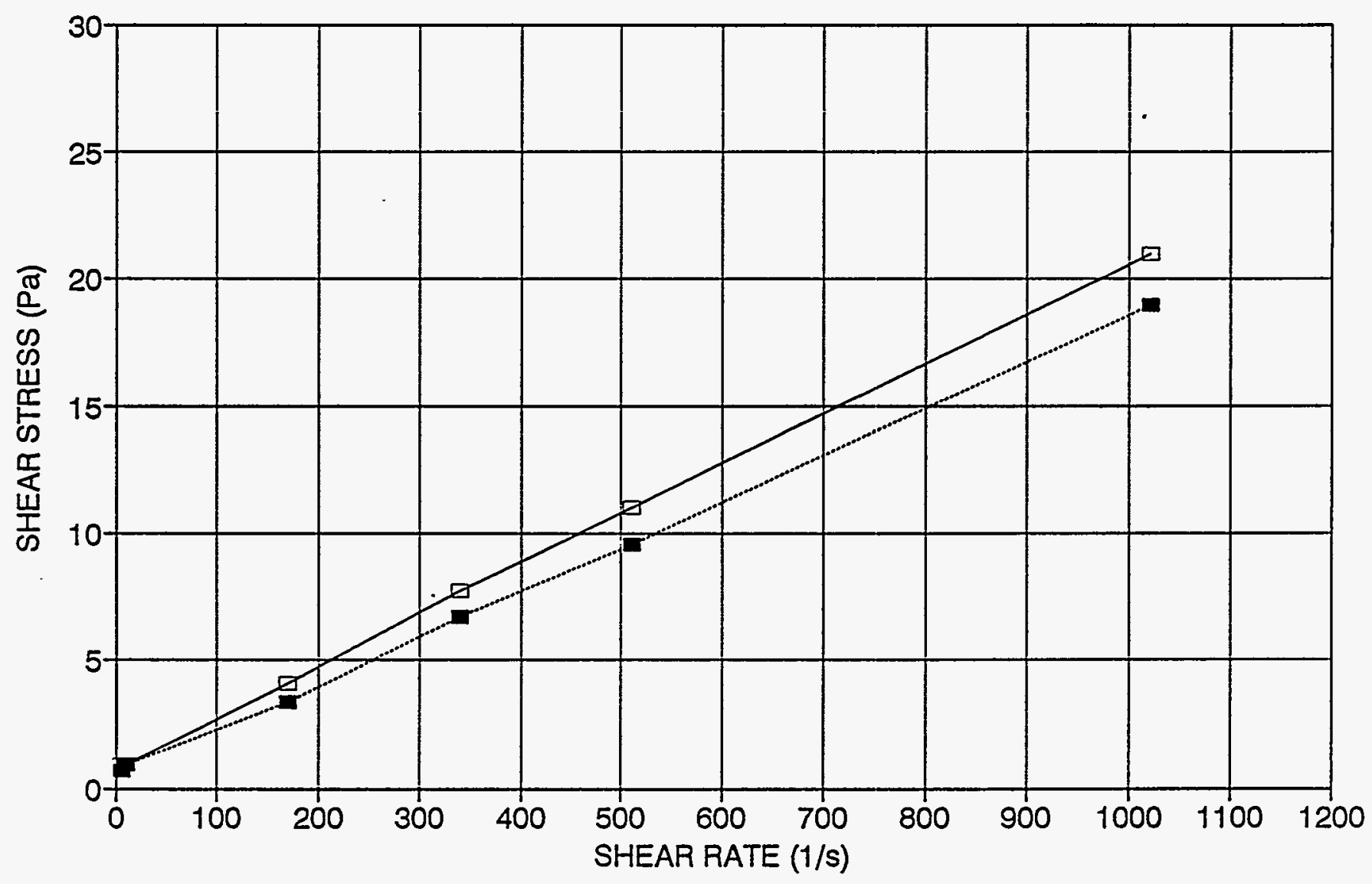

$\square 0.15$ SBR $\cdots 0.15$ ACR

Figure 8. Shear Stress-Shear Rate Curve for Latex-Modified Grouts with $40 \%$ Fly Ash, w/cm $=0.6$, $\mathrm{p} / \mathrm{cm}=0.15$. 


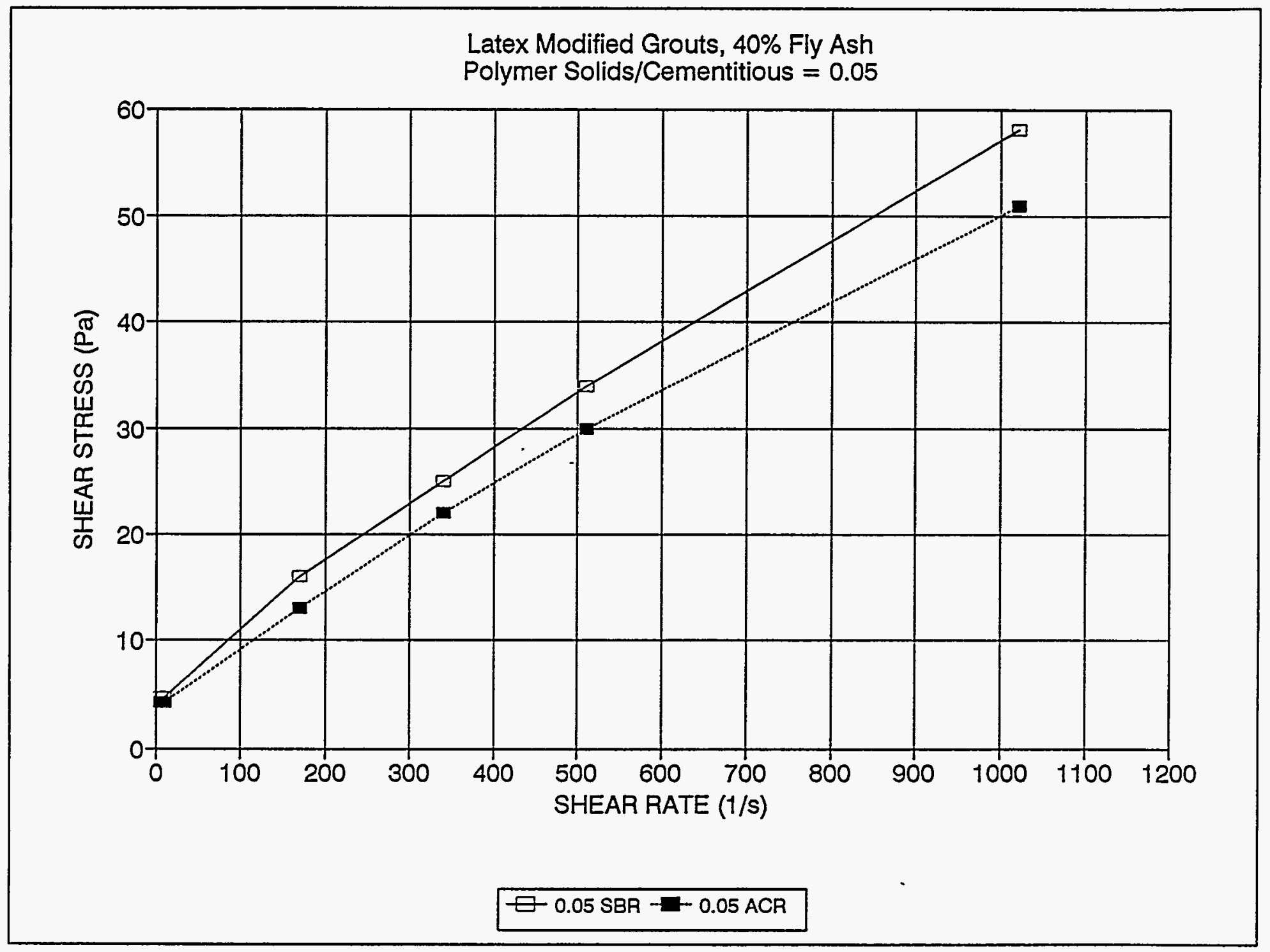

Figure 9. Shear Stress-Shear Rate Curve for Latex-Modified Grouts with $40 \%$ Fly Ash, w/cm $=$ $0.45, \mathrm{p} / \mathrm{c}=0.05$. 


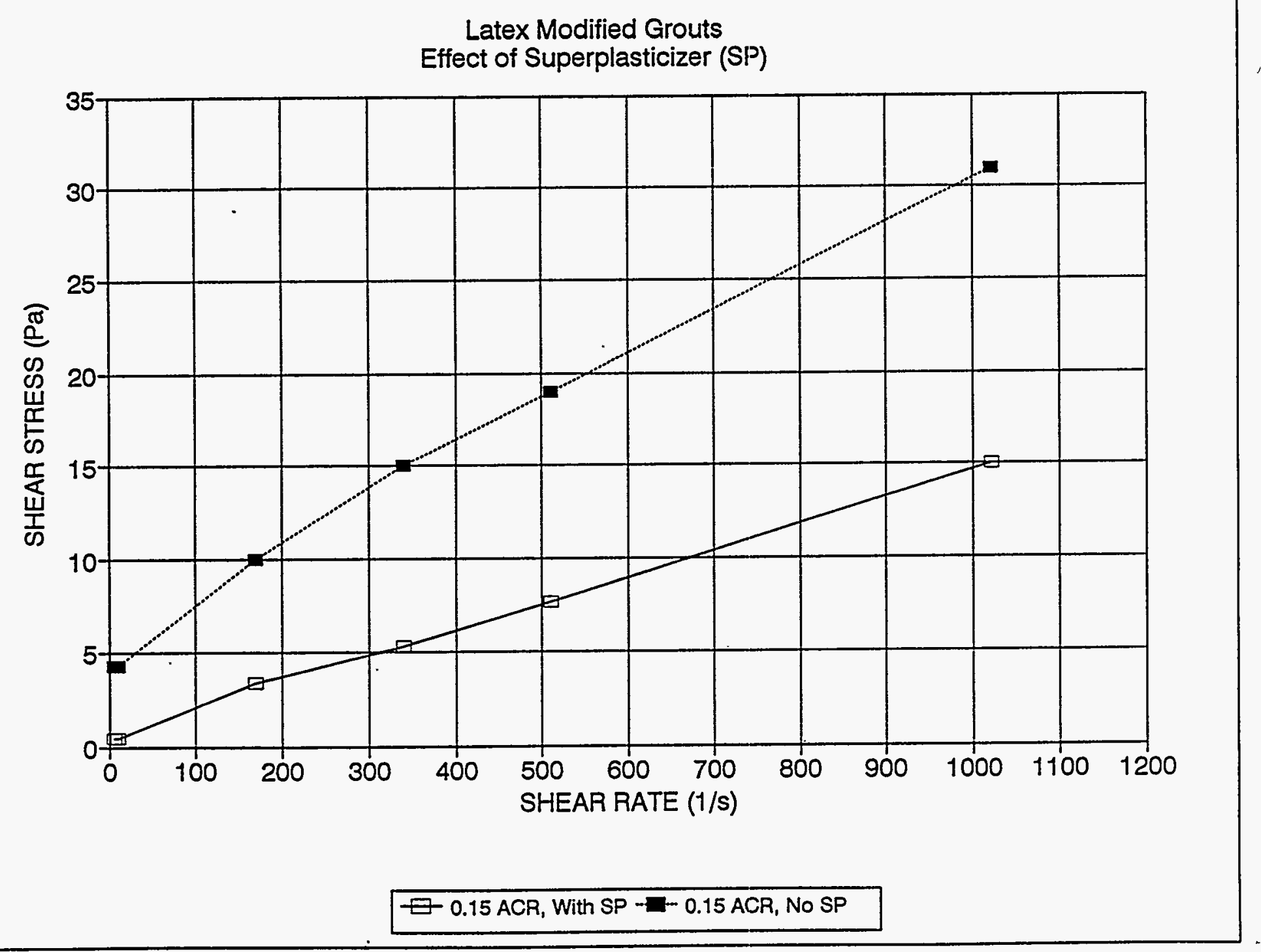

Figure 10. Effect of Superplasticizer on Shear Stress-Shear Rate Curve for Acrylic-Modified Grout with $\mathrm{w} / \mathrm{c}=0.6, \mathrm{p} / \mathrm{c}=0.15$. 


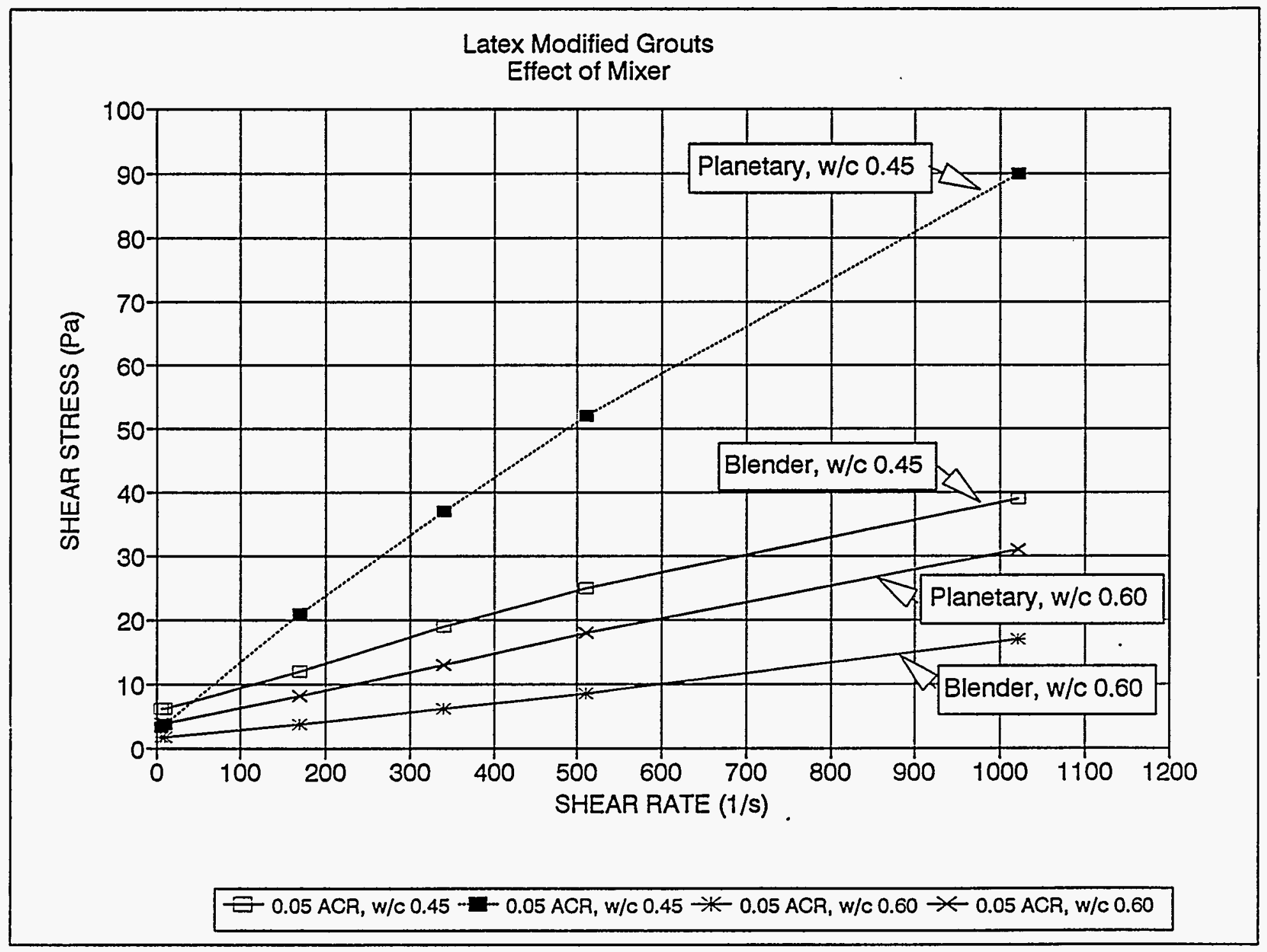

Figure 11. Effect of Mixer on Shear Stress-Shear Rate Curve for Acrylic-Modified Grout with w/c $=0.45$ and $0.6, \mathrm{p} / \mathrm{c}=0.05$. 
of grouts prepared in field scale mixers will differ from those reported here. Of particular importance are determination of the appropriate antifoam dosage, mixer type, and mixing procedure.

The apparent viscosity at $300 \mathrm{rpm}$ was measured on separate batches of the grouts. Assuming linearity and Bingham fluid behaviour, the plastic viscosity can be determined as the difference between the 600 and $300 \mathrm{rpm}$ dial readings. The yield point is calculated by subtracting the $300 \mathrm{rpm}$ dial reading from the plastic viscosity. Note that other theological models may be more appropriate than the Bingham for some of the grouts. The apparent and plastic viscosity and yield point data are presented in Tables 2-6.

Table 2. Rheology Data for Neat Cement Grouts

\begin{tabular}{|c|c|c|c|}
\hline Water/Cement Ratio & $\begin{array}{c}\text { Apparent Viscosity } \\
\text { (cP) }\end{array}$ & Plastic Viscosity (cP) & $\begin{array}{c}\text { Yield Point } \\
\left(\mathbf{l b} / \mathbf{1 0 0} \mathbf{f t}^{\mathbf{2}}\right)\end{array}$ \\
\hline 0.5 & 91 & 30 & 61 \\
\hline 0.6 & 48 & 14 & 34 \\
\hline 0.8 & 21 & 9 & 12 \\
\hline 1.0 & 12 & 7 & 5 \\
\hline 1.2 & 9 & 7 & 2 \\
\hline
\end{tabular}

Table 3. Rheology Data for Superplasticized Styrene Butadiene-Modified Grouts

\begin{tabular}{|c|c|c|c|c|}
\hline $\begin{array}{c}\text { Water/Cement } \\
\text { Ratio }\end{array}$ & $\begin{array}{c}\text { Polymer/Cement } \\
\text { Ratio }\end{array}$ & $\begin{array}{c}\text { Apparent } \\
\text { Viscosity (cP) }\end{array}$ & $\begin{array}{c}\text { Plastic } \\
\text { Viscosity (cP) }\end{array}$ & $\begin{array}{c}\text { Yield Point } \\
\left(\mathbf{l b} / \mathbf{1 0 0} \mathbf{f t}^{2}\right)\end{array}$ \\
\hline 0.45 & 0.05 & 47 & 31 & 16 \\
\hline 0.45 & 0.15 & 39 & 35 & 4 \\
\hline 0.50 & 0.15 & 29 & 24 & 5 \\
\hline 0.55 & 0.05 & 22 & 21 & 1 \\
\hline 0.60 & 0.05 & 17 & 16 & 1 \\
\hline 0.60 & 0.15 & 23 & 12 & 11 \\
\hline
\end{tabular}


Table 4. Rheology Data for Superplasticized Acrylic-Modified Grouts

\begin{tabular}{|c|c|c|c|c|}
\hline $\begin{array}{c}\text { Water/Cement } \\
\text { Ratio }\end{array}$ & $\begin{array}{c}\text { Polymer/Cement } \\
\text { Ratio }\end{array}$ & $\begin{array}{c}\text { Apparent } \\
\text { Viscosity (cP) }\end{array}$ & $\begin{array}{c}\text { Plastic } \\
\text { Viscosity } \\
\text { (cP) }\end{array}$ & $\begin{array}{c}\text { Yield Point } \\
\left(\mathbf{l b} / \mathbf{1 0 0} \mathbf{f t}^{\mathbf{2}}\right)\end{array}$ \\
\hline 0.45 & 0.05 & 52 & 30 & 22 \\
\hline 0.55 & 0.05 & 19 & 18 & 1 \\
\hline 0.60 & 0.05 & 17 & 17 & 0 \\
\hline 0.60 & 0.15 & 16 & 15 & 1 \\
\hline
\end{tabular}

Table 5. Rheology Data for Superplasticized Styrene Butadiene-Modified Grouts Containing Fly Ash

\begin{tabular}{|c|c|c|c|c|}
\hline w/cm & $\mathbf{p} / \mathbf{c m}$ & $\begin{array}{c}\text { Apparent } \\
\text { Viscosity (cP) }\end{array}$ & $\begin{array}{c}\text { Plastic } \\
\text { Viscosity (cP) }\end{array}$ & $\begin{array}{c}\text { Yield Point } \\
\left(\mathbf{l b}_{\mathbf{b}} / \mathbf{1 0 0} \mathbf{f t}^{\mathbf{2}}\right)\end{array}$ \\
\hline 0.45 & 0.05 & 71 & 49 & 22 \\
\hline 0.60 & 0.05 & 31 & 23 & 8 \\
\hline 0.60 & 0.15 & 23 & 20 & 3 \\
\hline
\end{tabular}

Table 6. Rheology Data for Superplasticized Acrylic-Modified Grouts Containing Fly Ash

\begin{tabular}{|c|c|c|c|c|}
\hline w/cm & $\mathrm{p} / \mathrm{cm}$ & $\begin{array}{c}\text { Apparent } \\
\text { Viscosity (cP) }\end{array}$ & $\begin{array}{c}\text { Plastic } \\
\text { Viscosity } \\
(\mathbf{c P})\end{array}$ & $\begin{array}{c}\text { Yield Point } \\
\left(\mathbf{l b}_{\mathbf{r}} / \mathbf{1 0 0} \mathbf{f t}^{2}\right)\end{array}$ \\
\hline 0.45 & 0.05 & 62 & 45 & 17 \\
\hline 0.60 & 0.05 & 27 & 22 & 5 \\
\hline 0.60 & 0.15 & 20 & 20 & 2 \\
\hline
\end{tabular}

\subsection{Flow Time}

The flow times of the grouts mixed in the planetary mixer and used to prepare soil cements are presented in Table 7. The Mix Codes correspond to those in Table 1. Note that lower flow times can be expected for grouts mixed with greater efficiency. 
Table 7. Flow Times of Grouts Mixed in Planetary Mixer

\begin{tabular}{|c|c|c|}
\hline \multirow{2}{*}{ Mix Code } & \multicolumn{2}{|c|}{ Flow Time (s) } \\
\cline { 2 - 3 } & ASTM C 939 Cone & Marsh Funnel (1000 ml) \\
\hline 1 & 9.3 & 33.1 \\
\hline 2 & 11.4 & 60.4 \\
\hline 3 & 10.9 & 55.3 \\
\hline 4 & 11.4 & 56.0 \\
\hline 5 & 11.0 & 57.4 \\
\hline
\end{tabular}

\subsection{Permeability}

The coefficient of permeability (hydraulic conductivity) was measured on saturated soil cements after 28 days of curing. The results are summarized in Table 8 . The mean and the standard deviation are reported. The Mix Codes are defined in Table 1.

Table 8. Permeability Results for Soil Cements

\begin{tabular}{|c|c|c|}
\hline Mix Code & Curing & Permeability $(\mathrm{cm} / \mathrm{s})$ \\
\hline 1 & 4 days $100 \% \mathrm{RH}, 24$ days ambient & $5.2 \times 10^{-7} \pm 6 \times 10^{-8}$ \\
\hline 1 & 28 days $100 \% \mathrm{RH}$ & $4.6 \times 10^{-8} \pm 3 \times 10^{-7}$ \\
\hline 2 & 4 days $100 \% \mathrm{RH}, 24$ days ambient & $1.9 \times 10^{-9} \pm 3 \times 10^{-8}$ \\
\hline 3 & 4 days $100 \% \mathrm{RH}, 24$ days ambient & $2.3 \times 10^{-9} \pm 4 \times 10^{-8}$ \\
\hline 4 & 4 days $100 \% \mathrm{RH}, 24$ days ambient & $5.2 \times 10^{-10} \pm 4 \times 10^{-11}$ \\
\hline 5 & 4 days $100 \% \mathrm{RH}, 24$ days ambient & $1.5 \times 10^{-9} \pm 2 \times 10^{-8}$ \\
\hline
\end{tabular}




\subsection{Compressive Strength}

The 28 day compressive strength results for the soil cements are presented in Table 9 .

Table 9. Compressive Strength Results for Soil Cements

\begin{tabular}{|c|c|c|}
\hline Mix Code & Curing & Compressive Strength (MPa) \\
\hline 1 & 4 days $100 \% \mathrm{RH}, 24$ days ambient & $5.4 \pm 0.9$ \\
\hline 1 & 28 days $100 \% \mathrm{RH}$ & $7.1 \pm 0.8$ \\
\hline 2 & 4 days $100 \% \mathrm{RH}, 24$ days ambient & $16.8 \pm 1.4$ \\
\hline 2 & 28 days $100 \% \mathrm{RH}$ & $9.4 \pm 0.8$ \\
\hline 3 & 4 days $100 \% \mathrm{RH}, 24$ days ambient & $11.6 \pm 1.0$ \\
\hline 4 & 4 days $100 \% \mathrm{RH}, 24$ days ambient & $20.7 \pm 2.2$ \\
\hline 5 & 4 days $100 \% \mathrm{RH}, 24$ days ambient & $12.2 \pm 0.9$ \\
\hline
\end{tabular}

\subsection{Antifoam Evaluation}

Based on the foam height comparisons, Dow Corning Antifoam B was found to give the best results. This was followed by Dow Corning 2210 . The acrylic latex had a greater tendency to foam even at high anitfoam dosages. Proper antifoam dosage, together with appropriate mixing procedure, should prevent foaming problems.

\subsection{MATERIAL COST ESTIMATES FOR LATEX-MODIFIED GROUTS}

The material costs for the superplasticized latex-modified grouts were estimated assuming bulk quantities of ingredients, including antifoam. The estimates are presented in Table 10. Costs for unmodified grouts were also calculated for comparison. The costs did not include freight. Also excluded are costs associated with mixing and placing the grouts. 
Table 10. Materials Cost Estimates for Grouts

\begin{tabular}{|c|c|c|c|c|c|}
\hline Latex & Grout Type & w/cm & p/cm & \$/kg & $\begin{array}{c}\text { S/US } \\
\text { gal. }\end{array}$ \\
\hline None & Neat cement & 1.0 & 0 & 0.031 & 0.18 \\
\hline None & $40 \%$ FA, SP & 0.45 & 0 & 0.094 & 0.64 \\
\hline ACR & $100 \%$ cement, SP & 0.45 & 0.05 & 0.203 & 1.40 \\
\hline ACR & $100 \%$ cement, SP & 0.45 & 0.15 & 0.473 & 3.11 \\
\hline ACR & $100 \%$ cement, SP & 0.60 & 0.05 & 0.192 & 1.24 \\
\hline ACR & $100 \%$ cement, SP & 0.60 & 0.15 & 0.433 & 2.69 \\
\hline ACR & $40 \%$ FA, SP & 0.45 & 0.05 & 0.196 & 1.30 \\
\hline ACR & $40 \%$ FA, SP & 0.45 & 0.15 & 0.462 & 2.93 \\
\hline SBR & $100 \%$ cement, SP & 0.45 & 0.05 & 0.190 & 1.31 \\
\hline SBR & $100 \%$ cement, SP & 0.45 & 0.15 & 0.407 & 2.68 \\
\hline SBR & $40 \%$ FA, SP & 0.45 & 0.05 & 0.182 & 1.21 \\
\hline SBR & $40 \%$ FA, SP & 0.45 & 0.15 & 0.400 & 2.54 \\
\hline
\end{tabular}

\subsection{DISCUSSION}

\subsection{Rheology}

The rheological studies demonstrated that suitable latex-modified grouts could be formulated. As with unmodified grouts, apparent and plastic viscosity decrease with increasing w/cm. Partial replacement of cement with fly ash increases viscosity. However, the potential benefits of fly ash counteract these slight increases. Addition of superplasticizer enables reduction of $\mathrm{w} / \mathrm{cm}$, and hence, improves durability.

The rheological properties of grouts mixed in field scale equipment will differ from those reported above. However, the trends should be the same. The flow times of the grouts will be reduced if a more efficient, high speed mixer is used. Also of importance are the effects of time and temperature on rheology. Latex-modified materials typically show a decrease in workability with time, although superplasticizers can delay this (Atzeni et al., 1989; Beaudoin and Ramachandran, 1989; Maximilien et al., 1994). 
A w/cm value of 0.45-0.6 appears suitable and this should be confirmed with field scale mixing and jet grouting trials. In terms of durability, the lower $\mathrm{w} / \mathrm{cm}$ is favoured and compatibility of such grouts with mixing and placement needs verification. The final $\mathrm{w} / \mathrm{cm}$ of the grouted waste will be higher due to the moisture content of the soil.

\subsection{Mixing Procedure}

The issue of field mixing procedure was not resolved since trials in field scale mixers were beyond the funding level. However, the laboratory mixing identified potential problems with excessive air entrainment if the latex-modified grouts are mixed at high speed. This is partially due to the configuration of the laboratory blender used since unmodified grouts also entrain air, although to a much smaller degree and collapse of any foam is rapid. Air entrainment is best prevented through use of an efficient antifoam and prevention of air entering the system, such as avoiding exposed impellers or not adding dry components to the latex.

Mixing in the low shear planetary mixer, together with using a suitable antifoam, solved the foaming problem. Past experience has shown that sanded latex-modified grouts can be successfully mixed in field scale paddle mixers. However, apparent and plastic viscosity of grouts mixed in such equipment are higher than for high shear mixers. It is proposed that tests should be performed in field scale paddle and colloidal mixers to determine the most suitable mixer and mixing procedure for jet grouting with latex-modified grouts. The mixing issue is not insurmountable and only requires appropriate tests with appropriate equipment to resolve.

\subsection{Permeability}

The coefficient of permeability tests demonstrated that values of the order of $10^{-9} \mathrm{~cm} / \mathrm{s} \mathrm{can}$ be achieved with laboratory-prepared soil cements at final $w / \mathrm{cm}=0.96$. The superplasticized, latexmodified grouts produced materials with significantly lower permeability than conventional neat cement grout with initial $w / c=1$ and final $w / c=1.42$. This material cracked when dried in air, thereby contributing to the high permeability. The latex-modified soil cements did not crack.

The effect of $w / \mathrm{cm}$ and latex was not separated in the preliminary tests. It is recommended that any field trials compare both modified and unmodified grouts with the same $\mathrm{w} / \mathrm{cm}$ so that the effect of latex can be quantified, particularly for subsurface curing conditions which were not replicated in this work. Of interest are the kinetics and extent of latex film formation in the subsurface environment. Without direct comparison of modified and unmodified grouts with equal w/cm placed with the same jet grouting parameters into the same environment it is not possible to determine unequivocally whether or not the additional cost of latex addition is justified.

Latex content and type was found to have only a slight impact on permeability of the materials studied. This may be due to the relatively high $w / \mathrm{cm}$ of the final product. The effect of fly ash was difficult to discern on the basis of the limited results. However, addition of fly ash to cementitious materials decreases permeability, particularly under long term moist curing. 
The permeability of jet grouted soil can be expected to vary from the results obtained in the laboratory studies. This is due to different mix proportions, particularly cementitious content, and in-situ curing conditions. The actual properties that can be achieved with the latex-modified grouts in the site conditions remains to be determined. Any increase in final $\mathrm{w} / \mathrm{cm}$ due to additional mixing water or high moisture content of the soil/waste to be grouted will result in higher permeability. This will have a negative impact on long-term durability.

\subsection{Compressive Strength}

As is the case for permeability, the presented results will differ from those of jet grouted soil due to changes in mix proportions and curing. The strength will decrease with a higher soil content than could be prepared in the laboratory. The high clay content of the INEL soil used to backfill the trenches will reduce strength. Any contaminants that interfere with the cement hydration process will also result in loss of strength. High strength is not required for the buried waste to be stabilized.

It was also shown that the curing conditions of latex-modified soil cement has a significant effect on strength. Mix 2 had lower strength when cured for 28 days at 100\% RH compared with four days at $100 \% \mathrm{RH}$ followed by 24 days at ambient RH (40-50\%). This decrease in strength of latex-modified materials is well documented (Ohama, 1984) and the effect has been measured previously on latex-modified soil cements (Allan and Kukacka, 1992). Latex-modified materials cured under dry conditions but tested after water absorption also show a decrease in strength (Ohama, 1984). Therefore, the moisture content of the latex-modified soil cement at the time of testing will exert strong influence on strength. Fracture properties are also expected to depend on moisture content and this has implications in retrievability of the grouted waste.

\subsection{Material Costs}

The cost estimates presented in Table 10 show that latex-modified grouts are more expensive than unmodified grouts, depending on the latex content. However, the grouts remain orders of magnitude cheaper than polymer and other chemical grouts that have been considered and tested at DOE sites. Addition of fly ash can reduce cost, although extra batching equipment would be required. Increasing the $w / \mathrm{cm}$ reduces grout cost and this needs to be balanced with the technical objectives. Superplasticizer and low $\mathrm{w} / \mathrm{cm}$ increase cost but can be expected to improve impermeability and long-term durability.

As shown, a neat cement grout with $w / c=1$ is very inexpensive in comparison. This grout may be adequate for soil stabilization and other geotechnical applications, depending on the properties targeted. However, stabilization of hazardous waste usually has more stringent requirements. Results obtained with high w/c grouts should not be generalized to encompass all cementitious materials lest false conclusions be made. The established benefits of lower w/cm and appropriate admixtures must be considered. 


\subsection{CONCLUSIONS}

Superplasticized, latex-modified grouts can be formulated to have appropriately low viscosity for jet grouting. The preliminary results suggest that the materials are suitable for jet grouting buried TRU/mixed waste, although more research and field trials are necessary to confirm this. Fly ash can be added to the latex-modified grouts to reduce heat of hydration and improve durability. The grouts were compatible with uncontaminated INEL soil. Relatively low permeabilities and reasonable compressive strengths were measured on moist INEL soil treated with latex-modified grouts. However, mix proportions of treated soil that would be achieved with jet grouting were difficult to reproduce in the laboratory. Also, in-situ curing conditions were not replicated. The properties of the treated soil prepared under laboratory conditions can be expected to vary from those produced in the field.

It is recommended that field-scale mixing trials be conducted to determine the most suitable mixer and mixing procedure for the latex-modified grouts to be used with jet grouting. Grouting field trials under site conditions, together with appropriate testing, are necessary to determine the characteristics of the latex-modified grouted waste. 


\subsection{REFERENCES}

M.L. Allan and L.E. Kukacka, In-Situ Containment and Stabilization of Buried Waste, Annual Report for Mixed Waste Landfill Integrated Demonstration, FY 1992, BNL 48252, Brookhaven National Laboratory, October, 1992.

M.L. Allan and L.E. Kukacka, In-Situ Containment and Stabilization of Buried Waste, Annual Report for Mixed Waste Landfill Integrated Demonstration, FY 1994, BNL 60977, Brookhaven National Laboratory, November, 1994a.

M.L. Allan and L.E. Kukacka, "Permeability and Microstructure of Plain and Polypropylene Fibre Reinforced Grouts," Cement and Concrete Research, Vol. 24, No. 4, 1994b, pp. 671-681.

M.L. Allan and L.E. Kukacka, "Strength and Durability of Polypropylene Fibre Reinforced Grouts," Cement and Concrete Research, Vol. 25, No. 3, 1995, pp. 511-521.

American Concrete Institute Committee 548, State-of-the-Art Report on Polymer Modified Concrete, 1990.

C. Atzeni, G. Mantegazza, L. Massidda, and U. Sanna, "Combined Effect of Superplasticizer and Acrylic Latex in Cement Mortars With and Without Silica Fume," in Superplasticizers and Other Chemical Admixtures in Concrete, V.M. Malhotra (ed.), ACI SP 119, American Concrete Institute, Detroit, 1989, pp. 457-470.

J.J. Beaudoin and V.S. Ramachandran, "Effect of Water Dispersible Polymers on the Properties of Superplasticized Cement Paste, Mortar, and Concrete," in Superplasticizers and Other Chemical Admixtures in Concrete, V.M. Malhotra (ed.), ACI SP 119, American Concrete Institute, Detroit, 1989, pp. 221-242.

A.L. Bell, (Ed.), Grouting in the Ground, Proceedings of the Institution of Civil Engineers Conference, Thomas Telford, London, 1994.

A.L. Bell and G.K. Burke, "The Compressive Strength of Ground Treated Using Triple System of Jet Grouting, in Grouting in the Ground," in Grouting in the Ground, A.L. Bell (Ed.), Proceedings of the Institution of Civil Engineers Conference, Thomas Telford, London, 1994, pp. 525-538.

S.M. Bernas, J.M. Oades, G.J Churchman, and C.D. Grant, "Comparison of the Effects of Latex and Poly(DADMAC) on Structural Stability and Strength of Soil Aggregates," Australian Journal of Soil Research, 33, 1995a, pp. 369-380.

S.M. Bernas, J.M. Oades, G.J Churchman, and C.D. Grant, "Effects of Latex and Poly(DADMAC) on Erosion, Hydrophobicity and Water Retention on Two Different Soils," Australian Journal of Soil Research, 33, 1995b, pp. 805-816. 
D.A. Bruce, "Jet Grouting," in Ground Control and Improvement, P.P. Xanthakos, L.W. Abramson, and D.A. Bruce, John Wiley and Sons, New York, 1994, pp. 580-683.

S. Chandra and Y. Ohama, Polymers in Concrete, CRC Press, Boca Raton, 1994.

D. Coutts, D.E. Hutchinson, and R.D. Essler, "Specification, Planning and Construction of Quay Wall Stabilisation Works at Kingston Bridge, Glasgow," in Grouting in the Ground, A.L. Bell (Ed.), Proceedings of the Institution of Civil Engineers Conference, Thomas Telford, London, 1994, pp. 433-453.

F. Gallavresi, "Grouting Improvement of Foundation Soils," in Proceedings of ASCE Conference on Grouting, Soil Improvement and Geosynthetics, New Orleans, V. 1, 1992, pp. 1-38.

H.N. Gazaway and B.B. Jasperse, "Jet Grouting in Contaminated Soils," in Proceedings of ASCE Conference on Grouting, Soil Improvement and Geosynthetics, New Orleans, V. 1, 1992, pp. 206214.

A.W. Gourlay and C.S. Carson, "Grouting Plant and Equipment," in Proceedings of ASCE Conference on Grouting in Geotechnical Engineering, New Orleans, 1982, pp. 121-135.

A.C. Houlsby, Construction and Design of Cement Grouting, John Wiley and Sons, New York, 1990.

J.L. Kauschinger, E.B. Perry, and R. Hankour, "Jet Grouting: State-of-the-Practice," in Proceedings of ASCE Conference on Grouting, Soil Improvement and Geosynthetics, New Orleans, V. 1, 1992, pp. 169-181.

D.R. Lankard, N. Thompson, M.M. Sprinkel, and Y.P. Virmani, "Grouts for Bonded Post-Tensioned Concrete Construction: Protecting Prestressing Steel from Corrosion," ACI Materials Journal, V. 90, No. 5, September-October, 1993, pp. 406-415.

J.A. Lavelle, "Acrylic Latex-Modified Portland Cement," ACI Materials Journal, V. 85, No. 1, January-February, 1988, pp. 41-48.

T.S. McFarlane and R.D. Holtz, "Selection and Laboratory Evaluation of Modifying Additives for Soil-Cement-Bentonite," in Proceedings of ASCE Conference on Grouting, Soil Improvement and Geosynthetics, New Orleans, V. 2, 1992, pp. 1006-1018.

S. Maximilien, J. Ambroise, and J. Pera, "Influence of Acrylic Polymers on the Rheology of Mortars," Fourth CANMET/ACI International Conference on Superplasticizers and Other Chemical Admixtures in Concrete, ACI SP-148, Detroit, 1994, pp. 89-104. 
R.L. Newman, R.D. Essler, and C.S. Covil, "Jet Grouting to Enable Basement Construction in Difficult Ground Conditions," in Grouting in the Ground, A.L. Bell (Ed.), Proceedings of the Institution of Civil Engineers Conference, Thomas Telford, London, 1994, pp. 385-402.

T. Nishi, O. Kuriyama, M Matsuda, K. Chino and M. Kikuchi, "Porosity and Ion Diffusivity of LatexModified Cement," Materials Research Society Symposium Proceedings, V. 176, 1990, pp. 109-114.

Y. Ohama, "Polymer-Modified Mortars and Concretes," in Concrete Admixtures Handbook, V.S. Ramachandran (ed.), Noyes Publications, Park Ridge, 1984, pp. 337-429.

D. G. Paftis, "Improving the Flexural Strength of Fibre Reinforced Oil Well Cements by Addition of a Polymer Latex," Materials Research Society Symposium Proceedings, V. 370, 1995, pp. 565-571.

R. Parry-Davies, R.M.H. Bruin, G. Wardle, and M.G. Nixon, "Stabilization of Pier Foundation Using Jet Grouting Techniques," in Proceedings of ASCE Conference on Grouting, Soil Improvement and Geosynthetics, New Orleans, V. 1, 1992, pp. 156-168.

T.C. Powers, The Properties of Fresh Concrete, John Wiley and Sons, New York, 1968.

E.W. Raabe and S. Toth, "Producing Sealing Walls and Sealing Slabs by Applying the Soilcrete Process," Piling and Deep Foundations Conference, 1989, pp. 111-118.

D.K. Smith, Cementing, SPE, New York, 1990.

R.D. Spence, "Cost Estimate of Grouting the Proposed Test Pits and Idaho National Engineering Laboratory Using the ORNL-Recommended Grouts," ORNL/TM-10025, 1987.

O.K. Tallent, T.L. Sams, T. Tamura, T.T. Godsey, C.L. Francis, and E.W. Mc Daniel, "Grout Testing and Characterization for Shallow Land Burial Trenches at the Idaho National Engineering Laboratory," ORNL/TM-9881, 1987.

P. Tarricone, "Jet Grouting Gains," Civil Engineering, December, 1994, pp. 40-43.

P.B. Vorkinn and G.S. Sanders, "Cement Slurry Qualification, Field Mixing and Quality Assurance Procedures for Coiled Tubing Squeeze Operations in Prudhoe Bay, Alaska," SPE 26089, 1993.

D.G. Walters, "Comparison of Latex-Modified Portland Cement Mortars," ACI Materials Journal, V. 87, No.4, 1990, pp. 371-377.

J.P. Welsh and G.K. Burke, "Vertical Cutoffs and Bottom Sealing by Jet Grouting," Geoenvironment 2000 Proceedings, New Orleans, 1995, pp. 1207-1221. 